\title{
Spatial and temporal dynamics of stream chemistry in a forested watershed
}

\author{
K. B. Piatek ${ }^{1}$, S. F. Christopher ${ }^{2}$, and M. J. Mitchell ${ }^{3}$ \\ ${ }^{1}$ West Virginia University, Division of Forestry and Natural Resources, P.O. Box 6125, Morgantown, WV 26506, USA \\ ${ }^{2}$ State University of New York College at Buffalo, The Great Lakes Center, Buffalo, NY 14222, USA \\ ${ }^{3}$ State University of New York, College of Environmental Sciences and Forestry, 1 Forestry Drive, Syracuse, NY 13210, USA
}

Received: 11 August 2008 - Published in Hydrol. Earth Syst. Sci. Discuss.: 8 September 2008

Revised: 25 February 2009 - Accepted: 4 March 2009 - Published: 25 March 2009

\begin{abstract}
Spatial dynamics of solute chemistry and natural abundance isotopes of nitrate $\left({ }^{15} \mathrm{~N}\right.$ and $\left.{ }^{18} \mathrm{O}\right)$ were examined in seven locations and at the watershed outlet in 2001 and 2002 in a forest watershed in the Adirondack Mountains of New York State, USA. Temporal dynamics were examined during five discharge periods: winter, snowmelt, spring, summer, and fall, based on discharge levels at the watershed outlet. Solute concentrations were variable across space and time with significant $(p \leq 0.05)$ interaction effects. Year*period was significant for $\mathrm{pH}, \mathrm{NH}_{4}^{+}, \mathrm{NO}_{3}^{-}$, total $\mathrm{N}$, $\mathrm{DOC}$, and total $\mathrm{Al}$ suggesting that inter-annual variability in discharge levels was more important for these solutes than intra-annual variability. Period*sampling point was significant for $\mathrm{pH}, \mathrm{Mg}^{2+}, \mathrm{Ca}^{2+}$, sum of base cations, $\mathrm{Si}$, and total $\mathrm{Al}$ suggesting that the differences in concentration of these solutes among sampling points were moderated by discharge levels. In general, groundwater sources located in upper watershed controlled stream chemistry at higher elevations with highest $\mathrm{pH}, \mathrm{Ca}^{2+}$, sum of base cations, $\mathrm{Si}$, and $\mathrm{SO}_{4}^{2-}$ concentrations, with higher values in summer, and dilution effects during snowmelt. Two low elevation wetlands had a substantial influence over stream chemistry at those locations contributing lowest $\mathrm{NO}_{3}^{-}$and highest DOC. Snowmelt exhibited among the lowest $\mathrm{pH}$, sum of base cations, and $\mathrm{SO}_{4}^{2-}$, and highest $\mathrm{NO}_{3}^{-}$, total $\mathrm{N}$, and total $\mathrm{Al}$; snowmelt appeared to dilute groundwater, and flush stored soil-derived solutes. Summer discharge, composed mainly of groundwater, exhibited the lowest flow, among the highest $\mathrm{Mg}^{2+}, \mathrm{Ca}^{2+}$, and lowest DON, DOC, and total $\mathrm{Al}$ concentrations. Isotopic anal-
\end{abstract}

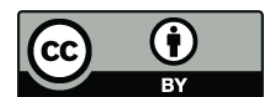

Correspondence to: K. B. Piatek (kathryn.piatek@mail.wvu.edu) ysis indicated that $\mathrm{NO}_{3}^{-}$was microbial with primary source in upper watershed soil, from where it was flushed to stream under high discharge-conditions, or drained to groundwater which became its secondary source when discharge was low. Watershed outlet did not exhibit specific solute levels found at source-areas, but represented solute dynamics in the rest of the watershed well.

\section{Introduction}

Solute concentrations in streams draining forested watersheds are important indicators of ecosystem health. A notable example of that is the export of nitrate $\left(\mathrm{NO}_{3}^{-}\right)$from forests impacted by elevated atmospheric deposition of nitrogen (N) (Stoddard, 1994; Aber et al., 1989, 1998, 2002). Nitrate and sulfate exports are associated with the losses of $\mathrm{Ca}^{2+}$ and $\mathrm{Mg}^{2+}$ with possible increases in soil acidity and potential decreases in forest productivity. Pristine forests exhibit more dissolved organic N (DON) than polluted forests (Perakis and Hedin, 2001), while more extreme hydrologic regimes that are predicted for a changing climate may impact transfer of dissolved organic C (DOC) between systems (Eimers et al., 2008; Harrison et al., 2008).

Spatial dynamics of stream chemistries seem to be mostly determined by topographic positions of sources (Creed et al., 1996; Boyer et al., 1997; Welsch et al., 2001; Inamdar et al., 2004). Surface water at the base of a watershed integrates the chemical response of the entire watershed; whether or not the base of the watershed provides sufficient resolution of the spatial variation of surface water chemistry within the watershed has not been confirmed (Ogawa et al., 2006; Ito et al., 2007). 
Temporal dynamics of solute concentrations are a complex result of differing patterns of solute production and consumption integrated via hydrologic pathways. High solute concentrations in surface waters may be present when net generation is high and under soil moisture conditions conducive to transport of solutes from the source of generation to streams (Creed and Band, 1998; Buffam et al., 2001; Welsch et al., 2001; Inamdar et al., 2004; Piatek et al., 2005; Mitchell et al., 2006). Low solute concentrations may be due to low rates of production when microbial activity or weathering rates are low, relatively high rates of consumption, or lack of hydrological connection between source and stream.

Changes in hydrology and resultant changes in surface water chemistry provide insights on solute sources. For example storm events often exhibit a shift in hydrologic flowpaths from ground water to soil horizons, and result in dilution of base cation and silica concentrations at peak flow (Harriman et al., 1990; Hill, 1993). On the other hand, solutes generated in mineral soil peak with increasing discharge (Hill, 1993). The largest $\mathrm{NO}_{3}^{-}$fluxes from forested watersheds in the US occur with large runoff events, especially during early spring snowmelt when vegetation and microbial uptake of inorganic N is low (Mitchell et al., 1996; Baron and Campbell, 1997; Brooks and Williams, 1999; Park et al., 2003; Inamdar et al., 2004; Piatek et al., 2005). The presence of wetlands and changes in vegetative cover from coniferous to deciduous may be related to the generation and loss rates of organically-bound elements, such as DOC, DON, and $\mathrm{Al}$ (Campbell et al., 2002; Mitchell et al., 2003; Ito et al., 2005).

The Archer Creek watershed in the central Adirondack Mountains of New York State, USA, has been a site of extensive hydrobiogeochemical studies since the early 1990s. The area receives atmospheric $\mathrm{N}$ and $\mathrm{S}$ at rates of $10.1 \mathrm{~kg} \mathrm{Nha}^{-1} \mathrm{yr}^{-1}$ and $6.3 \mathrm{~kg} \mathrm{Sha}^{-1} \mathrm{yr}^{-1}$ (Park et al., 2003), and generates stream $\mathrm{NO}_{3}^{-}$exports of $4.2 \mathrm{~kg} \mathrm{Nha}^{-1} \mathrm{yr}^{-1}$ (Mitchell et al., 2001). Previous studies in this watershed increased our understanding of the regulation of solute fluxes during high-discharge hydrologic events. Snowmelt and storm activity, for example, flush $\mathrm{NO}_{3}^{-}$to stream from sites of nitrification in upland soils (Ohrui et al., 1999; McHale et al., 2002; Inamdar et al., 2004; Piatek et al., 2005; Mitchell et al., 2006; Christopher et al., 2008). During these events, groundwater table rises to the upper soil horizons and establishes connectivity with the stream channel (Inamdar et al., 2004; Christopher et al., 2006). Postevent draining of $\mathrm{NO}_{3}^{-}$to groundwater, facilitated by steep slopes, probably serves to recharge groundwater $\mathrm{NO}_{3}^{-}$(Inamdar et al., 2004). In this system, groundwater appears to become the primary source of $\mathrm{NO}_{3}^{-}$to stream during periods of high $\mathrm{N}$ demand by biota (summer), low rates of nitrification, or lack of water movement through the soil profile (under the snowpack) (McHale et al., 2002; Inamdar et al., 2004; Piatek et al., 2005; Mitchell et al., 2006).
Our understanding of the sources of DOC during highdischarge events of summer and fall is that near-surface soil water, and runoff from wetlands are the primary sources, with isolated saturated areas contributing when soil moisture conditions facilitate their connectivity with stream (Inamdar et al., 2004; Mitchell et al., 2006). Wetlands were a source of $\mathrm{SO}_{4}^{2-}$ during consecutive fall storms which followed an unusually dry summer; the processes responsible were decomposition and $\mathrm{S}$ mineralization of wetland organic matter in unusually dry conditions, followed by runoff (Mitchell et al., 2006).

Finally, high-flow events result in increases in acidity in stream water, with potential consequences for aquatic habitat. This is especially acute during snowmelt, but was also observed during consecutive fall storms that followed an unusually severe dry spell (Mitchell et al., 2006).

We now explore how these earlier observations focusing on the watershed outlet at high discharge periods extrapolate across the watershed and across different discharge volumes. This will shed light on the generality of the mechanisms described for high discharge events, and facilitate future modeling efforts to determine possible effects on solute generation during extreme weather predicted under climate change scenarios. Our primary objective was to identify the spatial and temporal dynamics of solute chemistry in a stream draining a forested watershed to better understand factors responsible for solute expression at the watershed outlet. We hypothesized that an extensive wetland present in the lower part of the watershed will have an important effect on stream chemistry. Our analysis included two years, one of which had a very high discharge at snowmelt, and one with a summer drought followed by several late summer/early fall storms; these hydrologically-distinct periods allowed us to test their particular effects on stream water chemistry.

\section{Methods}

\subsection{Site description}

The study was conducted in the 135-ha Archer Creek catchment of the Arbutus Lake Watershed near the town of Newcomb $\left(43^{\circ} 58^{\prime} \mathrm{N}, 74^{\circ} 14^{\prime} \mathrm{W}\right)$ in the Adirondack Park of New York State, USA (Fig. 1). Elevation of the watershed extends from 550 to about $700 \mathrm{~m}$ a.s.l. The area includes ridges, rocky hillsides, and wetlands. The Arbutus Lake watershed is within the Anorthosite Massif, a large igneous intrusion composed of up to $90 \%$ calcium-rich feldspar. Upland soils are coarse loamy, isotic, frigid, oxyaquic Haplorthods of the Becket-Mundal association, and are generally less than $1 \mathrm{~m}$ thick. Wetlands consist of Greenwood mucky peats from 1 to $5 \mathrm{~m}$ thick (Somers, 1986; McHale, 1999). Boulders and stones dominate the soil profile, originating from glacial till deposits from the continental glaciation that retreated 10000 to 15000 years ago. High sand $(75 \%)$ and low clay $(<10 \%)$ 
content of the parent material provide for good drainage. Climate is characterized as continental. Mean annual temperature is $4.4^{\circ} \mathrm{C}$ and mean annual precipitation is $1010 \mathrm{~mm}$ (mean from 1951 to 1980; Shepard et al., 1989).

Vegetation consists of mixed hardwood-conifer stands typical of the northern hardwood forest. Fagus grandifolia Ehrh. (American beech) and Acer saccharum Marsh. (sugar maple) dominate the overstory at mid- and higher elevations, while Tsuga canadensis (L.) Carr. (eastern hemlock) and Picea rubens Sarg. (red spruce) dominate at lower elevations. Abies balsamea (L.) Mill. (balsam fir) and Pinus strobus L. (eastern white pine) are scattered throughout the watershed. Some of the wetlands support Alnus incana spp. rugosa (Du Roi) Clausen (speckled alder), an N-fixing species (Bischoff et al., 2001; Hurd et al., 2001).

Archer Creek has several tributaries (Fig. 1). One of them, located at elevation of about $650 \mathrm{~m}$ (S14), exhibits unusually high $\mathrm{NO}_{3}^{-}$concentrations throughout the year and is fed by deep groundwater (McHale et al., 2002; Christopher et al., 2006, 2008). At low elevations, another tributary forms an extensive conifer wetland (S11) before it resumes channelized flow into an open grassy field. Archer Creek also flows through a small alder wetland about $30 \mathrm{~m}$ before it empties into Arbutus Lake.

\subsection{Stream discharge and water chemistry}

Stream discharge was monitored on Archer Creek during 2001 and 2002 at an H-flume located $10 \mathrm{~m}$ away from the lake inlet. The flume was enclosed, and equipped with automated stage-height recording at 15-min intervals. In winter, a heater kept the water inside the flume enclosure above freezing point. Fifteen-minute data were averaged to obtain daily values. Discharge exhibits substantial variability over a course of a year, and we identified specific discharge periods. These periods were: winter, snowmelt, spring, summer, and fall. Specific dates which correspond to these periods are listed in Table 1. For comparison, the length of corresponding discharge periods in both years was adjusted to the same number of days (Table 1).

Stream water was sampled weekly at the H-flume by autosamplers, and every two hours during storms in fall 2002 by "grab" samples. Stream water elsewhere in the catchment was sampled monthly by grab samples. For that purpose, seven sampling locations, spanning the elevation range of the Archer Creek catchment, were established (S15, S14, S13, S12, S10, S11, S9) (Fig. 1). The difference in elevation between the highest- and lowest-lying stream sampling locations is about $61 \mathrm{~m}$, stretching over about $6 \mathrm{~km}$. All but two of the sampling locations are separate tributaries to the main stream channel (S15, S14, S13, S12, S11, S10), and their solute concentrations are thought to be spatially independent (Legendre and Fortin, 1989; Wagener et al., 1998; Dent and Grimm, 1999). Further, parts of the Archer Creek system are steep and fast-flowing. Watershed outlet (S2) and

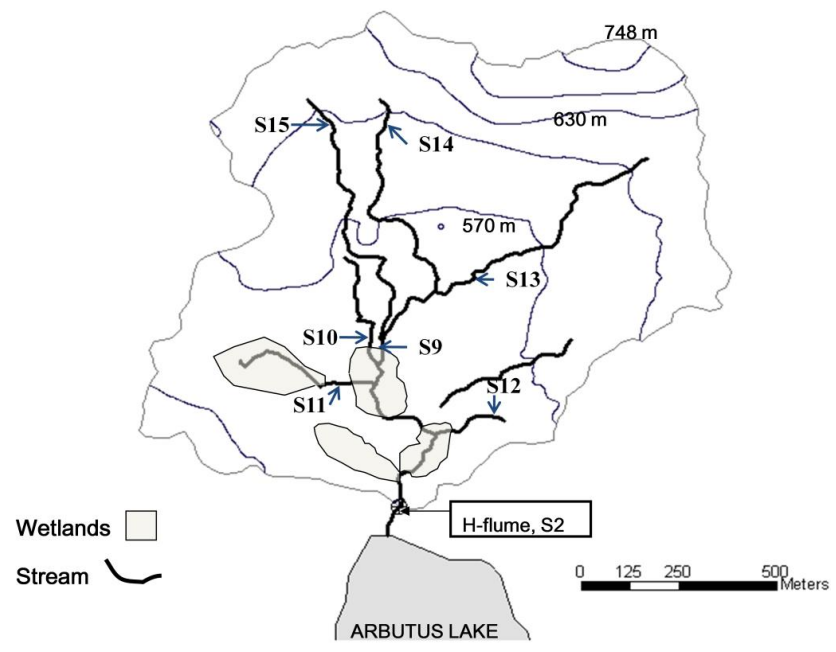

Fig. 1. Arbutus Lake Watershed in the Adirondack Mountains of New York, USA with locations of sampling points and elevations.

S9 are nested mixing points. Due to their substantially different chemistry, stream points S11, S14, and S15 were sampled for parts of the year in 2002 with autosamplers approximately biweekly during baseflow, hourly during summer/fall storms, and daily during snowmelt. These more frequent data were also averaged to obtain daily values.

Silica concentration was first measured in January 2002. After collection, samples for chemical analyses were shipped on ice to the Biogeochemistry Laboratory at SUNY-ESF in Syracuse, NY, where they were analyzed as follows: $\mathrm{NO}_{3}^{-}$ and $\mathrm{SO}_{4}^{2-}$ on a Dionex IC, DOC on a Tekmar-Dohrmann Phoenix 8000 TOC analyzer, $\mathrm{K}^{+}, \mathrm{Na}^{+}, \mathrm{Ca}^{2+}, \mathrm{Mg}^{2+}$, total $\mathrm{Al}$ and dissolved Si on a Perkin-Elmer ICP-AEC Div 3300 instrument, $\mathrm{NH}_{4}^{+}$by continuous flow colorimetry, total dissolved $\mathrm{N}$ (TDN) by persulphate oxidation, $\mathrm{pH}$ by glass electrode potentiometry, and DON was calculated by subtracting dissolved inorganic $\mathrm{N}\left(\mathrm{NH}_{4}^{+}+\mathrm{NO}_{3}^{-}\right)$from TDN. All DOC samples were filtered with $0.5 \mu \mathrm{m}$ glass fiber filter prior to analysis. Potassium and $\mathrm{Na}^{+}$are not reported here; however, they were included with $\mathrm{Mg}^{2+}$ and $\mathrm{Ca}^{2+}$ in the calculation of the sum of base cations $\mathrm{C}_{\mathrm{b}}$. The biogeochemistry laboratory is a participant in the US Geological Survey performance evaluation program to ensure data quality. A system of calibration QC, detection QC, analytical blanks and replicates is used with every set of samples (Mitchell et al., 2001).

\subsection{Sample collection for natural abundance isotopes}

Stream water was sampled at the $\mathrm{H}$-flume for natural abundance isotopes of $\mathrm{NO}_{3}^{-}\left({ }^{15} \mathrm{~N}\right.$ and $\left.{ }^{18} \mathrm{O}\right)$ bi-weekly during the snowmelt of 2001 and 2002, every four hours during fall storms of 2002, and monthly the rest of the time. Stream water in all other locations was tested once a month during the study period, except when snow hindered access. Reported 
Table 1. Discharge periods (based on flow level), discharge diagnostics, and corresponding dates for 2001 and 2002. Data adjusted to reflect equal number of days in both years (actual number of days given).

\begin{tabular}{|c|c|c|c|c|c|}
\hline & \multirow[b]{2}{*}{$\begin{array}{c}\text { Adjusted } \\
\text { \# of } \\
\text { days }\end{array}$} & \multicolumn{2}{|c|}{2001} & \multicolumn{2}{|c|}{2002} \\
\hline & & $\begin{array}{r}\text { Adjusted cumulative } \\
\text { discharge in mm } \\
\text { (actual discharge; } \\
\% \text { of annual total) }\end{array}$ & $\begin{array}{l}\text { Dates included } \\
\text { (actual \# days) }\end{array}$ & $\begin{array}{r}\text { Adjusted cumulative } \\
\text { discharge in mm } \\
\text { (actual discharge; } \\
\% \text { of annual total) }\end{array}$ & $\begin{array}{l}\text { Dates included } \\
\text { (actual \# days) }\end{array}$ \\
\hline Winter & 120 & $142.3(147 ; 25 \%)$ & $\begin{array}{r}1 \text { Jan-3 Apr } \\
1-31 \text { Dec (124) }\end{array}$ & $173.2(170 ; 24 \%)$ & $\begin{array}{r}\text { 1 Jan-28 Mar } \\
1-31 \text { Dec (117) }\end{array}$ \\
\hline Snowmelt & 30 & $252.1(269 ; 46 \%)$ & 4 Apr-5 May (32) & $191.3(191 ; 26 \%)$ & 29 Mar-27 Apr (30) \\
\hline Spring & 60 & $129.3(121 ; 1 \%)$ & 6 May-30 Jun (56) & $121.3(131 ; 18 \%)$ & $28 \mathrm{Apr}-30$ Jun (65) \\
\hline Summer & 80 & $16.7(17 ; 3 \%)$ & 1 Jul-19 Sep (81) & $3.0(3 ; 0.4 \%)$ & 1 Jul-21 Sep (83) \\
\hline Fall & 70 & $31.7(33 ; 6 \%)$ & 20 Sep-30 Nov (72) & $64.8(65 ; 31 \%)$ & 22 Sep-30 Nov (70) \\
\hline TOTAL & & 586 & & 561 & \\
\hline
\end{tabular}

isotopic values for $\delta^{18} \mathrm{O}$ of $\mathrm{NO}_{3}^{-}$of throughfall, bulk precipitation, and snow in this region (Northeastern US) have a seasonal variation of only 2-4\% (Pardo et al., 2004); therefore, atmospheric $\mathrm{NO}_{3}^{-}$values from this watershed reported earlier by Piatek et al. (2005) were used as comparisons.

Samples for natural abundance isotopic analysis of nitrate were prepared using the microbial denitrifier method (Sigman et al., 2001; Casciotti et al., 2002) at the USGS Isotopic Laboratory in Menlo Park, CA, USA, and analyzed on a Micromass IsoPrime stable isotope mass spectrometer. The reported values are defined as:

$\delta^{15} \mathrm{~N}=\left({ }^{15} \mathrm{~N} /{ }^{14} \mathrm{~N}_{\text {sample }}\right) /\left({ }^{15} \mathrm{~N} /{ }^{14} \mathrm{~N}_{\text {standard }}-1\right) * 1000[\%$ o $]$

$\delta^{18} \mathrm{O}=\left({ }^{18} \mathrm{O} /{ }^{16} \mathrm{O}_{\text {sample }}\right) /\left({ }^{18} \mathrm{O} /{ }^{16} \mathrm{O}_{\text {standard }}-1\right) * 1000[\%$ o $]$

Procedural quality was controlled. First, most of the samples collected at the H-flume were collected, processed, and analyzed in duplicate, except in very few cases where nitrate levels were too low. Duplicate isotopic determinations on each sample were averaged. Second, USGS Isotopic Laboratory uses internationally accepted standards for $\delta^{18} \mathrm{O}-\mathrm{NO}_{3}^{-}$, with $\delta^{15} \mathrm{~N}$ of $15.96 \%$ relative to air nitrogen, and with $\delta^{18} \mathrm{O}$ of $19.6 \%$ relative to SMOW. Analytical precision for our samples was $\pm 0.6 \%$ oror $\delta^{15} \mathrm{~N}$ and $\pm 0.7 \%$ o for $\delta^{18} \mathrm{O}$.

\subsection{Statistical analysis}

We tested differences in the concentration of solutes among years (2001, 2002), stream sampling locations (S2 to S15), and discharge periods (winter, snowmelt, spring, summer, and fall) with analysis of variance in SAS (SAS Institute $($ ). We used the "weight" statement to adjust for unequal sample number across locations. Our model was:

$$
\begin{aligned}
{[C]_{i j k}=} & \mu+Y_{i}+S_{j}+(Y S)_{i j}+P_{k}+(Y P)_{i k}+(S P)_{j k} \\
& +(Y S P)_{i j k}+e_{i j k},
\end{aligned}
$$

where

$[C]=$ observed solute concentration

$\mu=$ overall mean observation

$Y_{i}=$ fixed effect of year $(i=1,2)$

$S_{j}=$ fixed effect of stream sampling points $(j=2-15)$

$Y S_{i j}=$ fixed effect of interaction of year and location of sampling point

$P_{k}=$ fixed effect of discharge period $(k=1-5)$

$Y P_{i k}=$ fixed effect of interaction of year and discharge period

$S P_{j k}=$ fixed effect of interaction of sampling point and discharge period

$Y S P_{i j k}=$ fixed effect of a three-way interaction of year, location, and period, and

$e_{i j k}=$ random error term.

\subsection{Relationships among solutes across space and time}

We performed linear regression analyses of solute concentrations at their individual locations and at different discharge periods against key source indicators of groundwater $(\mathrm{Si})$, mineral soil (Total Al), and forest floor or wetland (DOC) to better understand sources of the solutes. Further, relationships of specific solute with $\mathrm{NO}_{3}^{-}$concentrations were also explored. Nitrate could be thought of as an indicator of $\mathrm{N}$ saturation in the system; with a decreasing capacity of ecosystem to retain atmospheric $\mathrm{N}$ inputs, watersheds leak more $\mathrm{NO}_{3}^{-}$(Stoddard, 1994).

\subsection{Relationships of solutes to discharge}

We performed linear regression analyses of solute concentrations at each location against daily, current-period cumulative, and previous-period cumulative discharge to better understand how these relationships change across space. Daily discharge was discharge on a given day in $\mathrm{mm}$ per day, current-period cumulative discharge was total discharge added for adjusted number of days per period in $\mathrm{mm}$ per 
Table 2. Anova table for all solute concentrations (Type III SS). All values are weighted on the frequency of observations. DON and $\delta^{18} \mathrm{O}-\mathrm{NO}_{3}^{-}$were not significant for any effect in the model. Blank cells indicate non-significant effects at $p \leq 0.05$. n.a. $=$ data not available to evaluate effect.

\begin{tabular}{|c|c|c|c|c|c|c|c|c|c|c|c|c|}
\hline & $\mathrm{pH}$ & $\mathrm{NH}_{4}$ & $\mathrm{Mg}$ & $\mathrm{Ca}$ & $\mathrm{C}_{\mathrm{b}}^{1}$ & $\mathrm{Si}$ & $\mathrm{SO}_{4}^{2-}$ & $\mathrm{NO}_{3}^{-}$ & Total N & DOC & Total Al & $\delta^{15} \mathrm{~N}-\mathrm{NO}_{3}^{-}$ \\
\hline Year & & & & & & n.a. & & & & & & \\
\hline Sampling point (S) & 0.000 & & 0.000 & 0.000 & 0.000 & 0.000 & 0.000 & 0.000 & 0.000 & 0.000 & 0.000 & \\
\hline Period & & & 0.006 & 0.001 & 0.000 & 0.000 & & 0.000 & 0.000 & & 0.003 & 0.040 \\
\hline Year*S & & & & & & n.a. & & & & & & \\
\hline Year*Period & 0.004 & 0.000 & & & & n.a. & & 0.000 & 0.000 & 0.000 & 0.040 & \\
\hline Period*S & 0.004 & & 0.000 & 0.000 & 0.000 & 0.000 & & & & & 0.032 & \\
\hline
\end{tabular}

${ }^{1} \mathrm{C}_{\mathrm{b}}$ is the sum of basic cations: $\mathrm{K}^{+}, \mathrm{Na}^{+}, \mathrm{Mg}^{2+}$, and $\mathrm{Ca}^{2+}$.

period, and previous-period cumulative discharge was cumulative discharge for the period immediately preceding the one tested, in $\mathrm{mm}$ per period.

\section{Results}

\subsection{Stream discharge}

The adjusted length of discharge periods ranged from 30 days for snowmelt to 120 days for winter (Table 1). Adjusted cumulative discharge ranged from $3 \mathrm{~mm}$ in summer of 2002 to $252 \mathrm{~mm}$ during snowmelt of 2001 (Table 1).

3.2 Spatial dynamics in solute concentrations and isotopic composition

There were no statistically significant differences in concentrations between sampling year 2001 and $2002(p \geq 0.05)$. There were no statistical differences for DON or $\delta^{18} \mathrm{O}-\mathrm{NO}_{3}^{-}$ (Table 2). The average concentration of DON for the period of study was $8.0 \mu \mathrm{mol} \mathrm{L}^{-1}$ (SE \pm 3.0$)$. The average value of $\delta^{18} \mathrm{O}-\mathrm{NO}_{3}^{-}$for the period of study was $2.7 \%$ ( $\mathrm{SE} \pm 2.9$ ).

The main effect of stream sampling location was significant for $\mathrm{SO}_{4}^{2-}, \mathrm{NO}_{3}^{-}$, total $\mathrm{N}$, and DOC (Table 2, Fig. 2); interactions, significant for other solutes, are discussed below. At an average of $213 \mu \mathrm{mol} \mathrm{L}-1, \mathrm{SO}_{4}^{2-}$ concentrations were significantly higher at S14 and S15 than at S2, S10, and $\mathrm{S} 11$, at an average for these three locations of $130 \mu \mathrm{mol} \mathrm{L}^{-1}$. Other locations were comparable to each other (Fig. 2). Nitrate concentrations were highest at $\mathrm{S} 14$ at $70.5 \mu \mathrm{mol} \mathrm{L}{ }^{-1}$, and lowest at $\mathrm{S} 11$ at $14 \mu \mathrm{mol} \mathrm{L}^{-1}$ (Fig. 2). Total $\mathrm{N}$ followed the trend for $\mathrm{NO}_{3}^{-}$with highest concentrations at S14. Dissolved OC had substantial variability at $\mathrm{S} 12$ and S13, probably due to a low sample size. At $878 \mu \mathrm{mol} \mathrm{L}^{-1}, \mathrm{~S} 11$ generated $290 \mu \mathrm{mol} \mathrm{L}^{-1}$ more DOC than the next highest at S2, and both S11 and S2 discharged significantly more DOC than any other sampling location (Fig. 2).

The interaction effect of sampling location and period was significant for $\mathrm{NH}_{4}^{+}, \mathrm{Mg}^{2+}, \mathrm{Ca}^{2+}, \mathrm{C}_{\mathrm{b}}, \mathrm{Si}$, and total $\mathrm{Al}$ con-

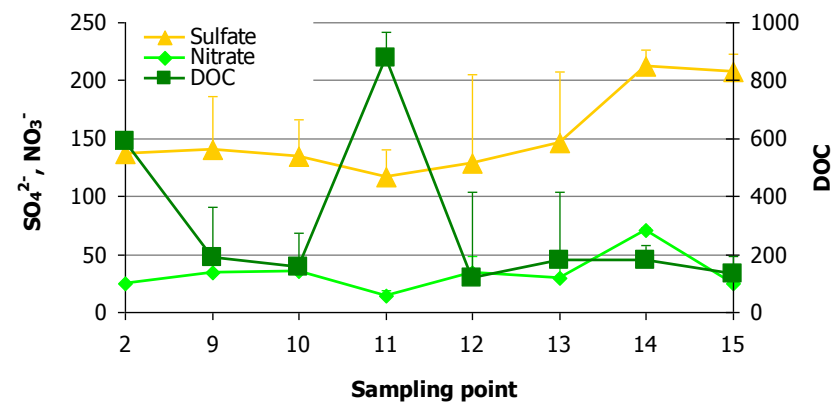

Fig. 2. Average concentrations $\left(\mu \mathrm{mol} \mathrm{L}^{-1}\right)$ of $\mathrm{NO}_{3}^{-}, \mathrm{SO}_{4}^{2-}$ and DOC (+ standard error) at individual sampling locations within the Archer Creek watershed.

centrations, and for $\mathrm{pH}$ (Table 2). These interactions indicate that period had a moderating effect on stream sampling location. Ammonium did not exhibit a significant pair-wise comparison, despite an overall significance of the interaction. The largest across-period variation in $\mathrm{Mg}^{2+}$ was observed at S15 (Fig. 3); snowmelt and spring exhibited among the lowest levels of $\mathrm{Mg}^{2+}$, and summer and fall among the highest. Calcium had a similar concentration pattern to $\mathrm{Mg}^{2+}$. At S2 to S11, snowmelt had among the lowest and summer among the highest $\mathrm{Ca}^{2+}$ concentrations. Highest $\mathrm{Ca}^{2+}$ levels were observed at $\mathrm{S} 14$ regardless of period, and in summer and fall at S15; winter, spring, and snowmelt $\mathrm{Ca}^{2+}$ levels at S15 were comparable to those elsewhere in the watershed (Fig. 3). Sum of base cations followed dynamics observed for $\mathrm{Mg}^{2+}$ and $\mathrm{Ca}^{2+}$ (Fig. 3).

Some of the highest $\mathrm{pHs}$ were consistently detected at $\mathrm{S} 14$ and S15, and among the lowest at S11 during snowmelt and spring. However, S14 in summer had somewhat lower $\mathrm{pH}$ than it did at snowmelt, and that was opposite of all other locations (Fig. 4). Due to insufficient data, interactions for $\mathrm{Si}$ could not be evaluated to the same degree as for the rest of the elements (Fig. 4). Total Al exhibited a large variability among sampling locations and periods. In general, S2, S11, and S13 exhibited the highest $\mathrm{Al}$ concentrations during 

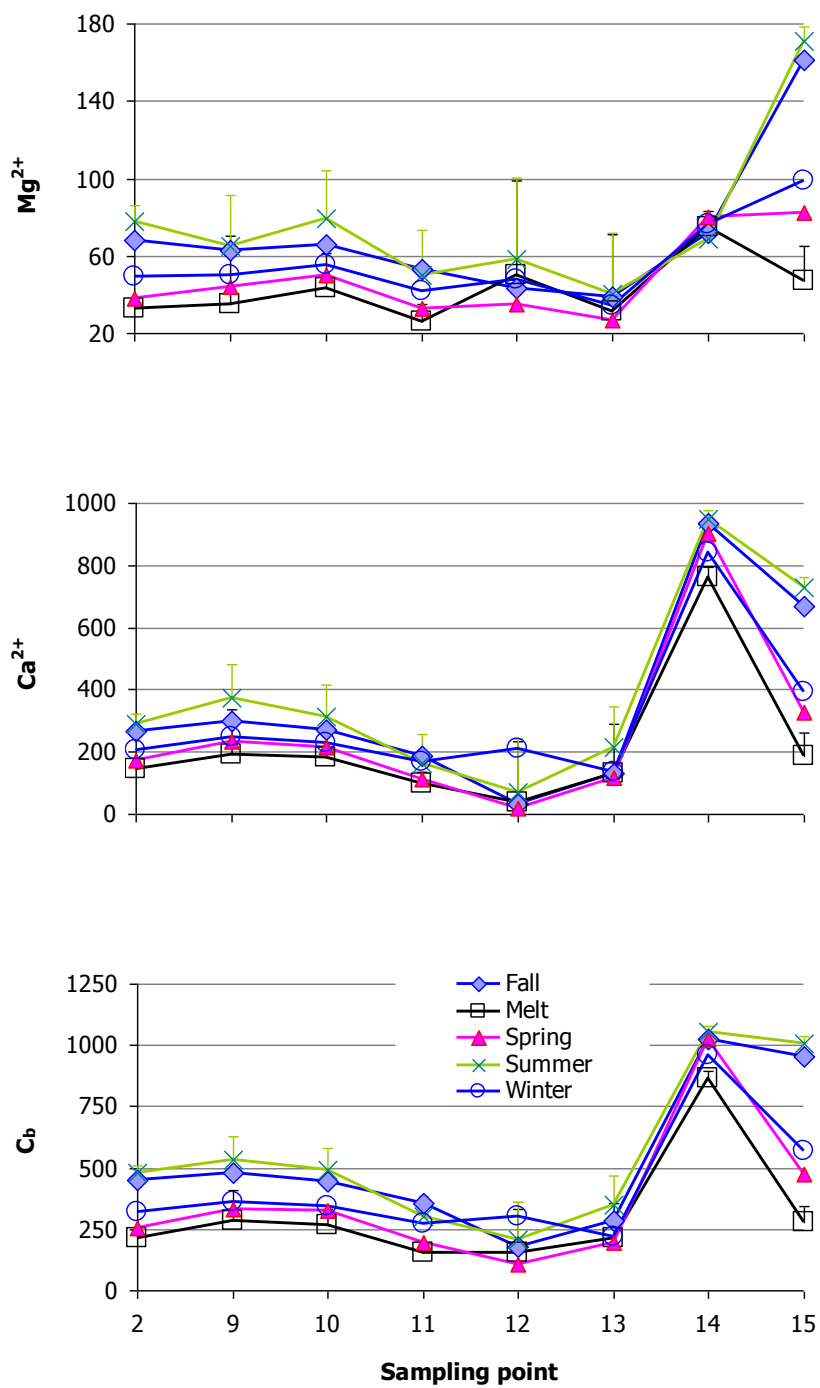

Fig. 3. Average concentrations $\left(\mu \mathrm{molL} \mathrm{L}^{-1}\right)$ of $\mathrm{Mg}^{2+}, \mathrm{Ca}^{2+}$, and sum of base cations $\mathrm{C}_{\mathrm{b}}\left(\mathrm{C}_{\mathrm{b}}\right.$ includes $\left.\mathrm{K}^{+}, \mathrm{Na}^{+}, \mathrm{Mg}^{2+}, \mathrm{Ca}^{2+}\right)$ for individual sampling locations during discharge periods within the Archer Creek watershed. Standard errors (+) shown for snowmelt and summer only.

snowmelt and spring, and S11 additionally during fall. Summer and fall also exhibited among the lowest $\mathrm{Al}$ at $\mathrm{S} 9$ and S12 at nearly 0. Both S14 and S15 exhibited consistently low Al throughout the year (Fig. 4).

\subsection{Relationships among solutes across sampling locations}

Increases in Si concentration coincided with increases in the concentration of $\mathrm{Mg}^{2+}, \mathrm{Ca}^{2+}, \mathrm{C}_{\mathrm{b}}$, and $\mathrm{SO}_{4}^{2-}$. Decreases were observed for $\mathrm{NO}_{3}^{-}$, DOC, DON, and total $\mathrm{Al}$ (Table 3, Fig. 5). Silica concentrations ranged from $50-250 \mu \mathrm{mol} \mathrm{L}^{-1}$ in most sampling locations but at S14, where it ranged from about 200 to $750 \mu \mathrm{mol} \mathrm{L}^{-1}$, changing these relationships to some degree at $\mathrm{S} 14$. For example, the increase in $\mathrm{C}_{\mathrm{b}}$ con-
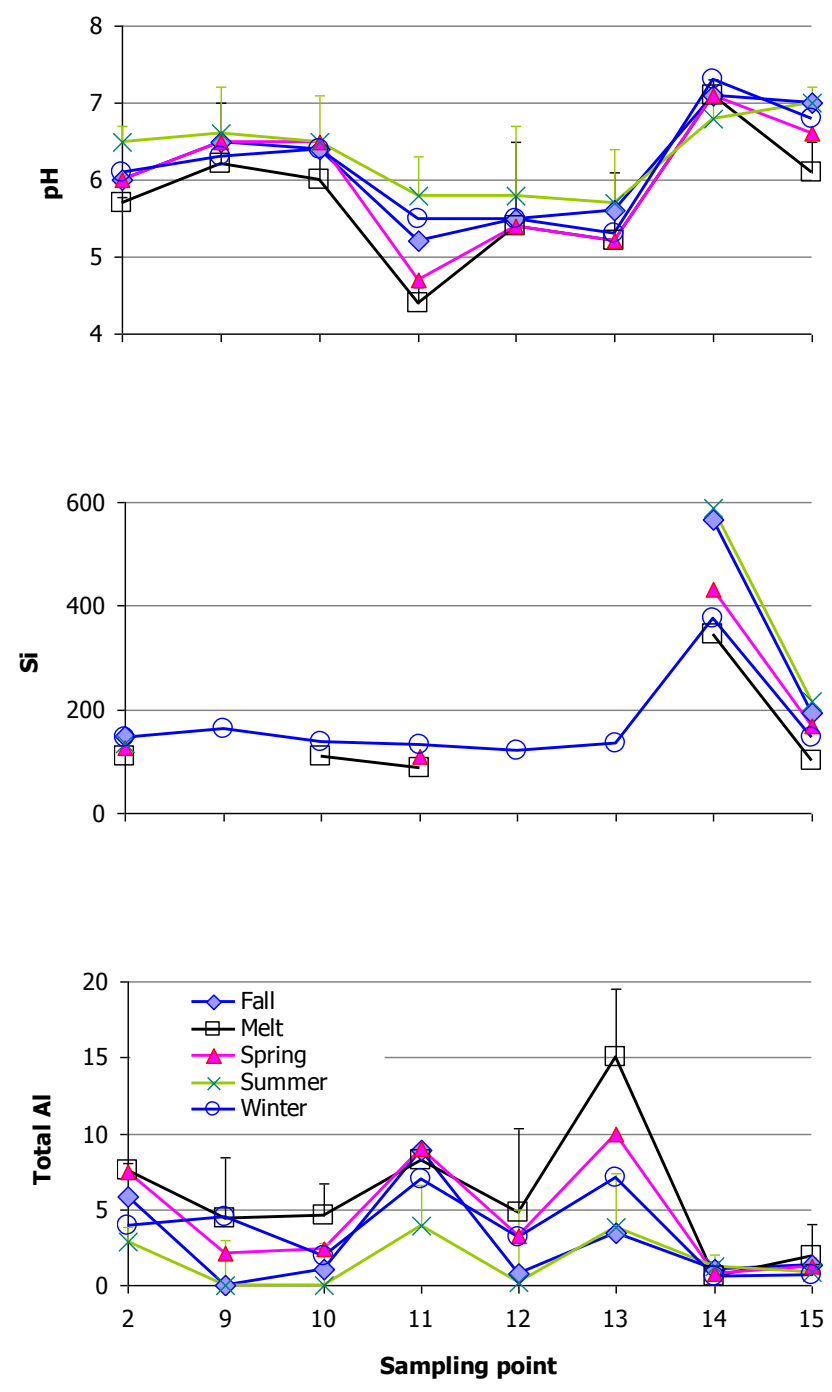

Fig. 4. Average $\mathrm{pH}$ and concentrations $\left(\mu \mathrm{mol} \mathrm{L}^{-1}\right)$ of $\mathrm{Si}^{1}$, and total Al for individual sampling locations during five discharge periods within the Archer Creek watershed. Standard errors (+) shown for snowmelt and summer only. ${ }^{1} \mathrm{Si}$ concentration not available for several interactions.

centration with Si was slower at S14 than elsewhere (Fig. 5), and the decrease in $\mathrm{NO}_{3}^{-}$with increasing $\mathrm{Si}$ was over much larger concentrations of both $\mathrm{NO}_{3}^{-}$and $\mathrm{Si}$ than elsewhere.

Concentrations of $\mathrm{Mg}^{2+}, \mathrm{Ca}^{2+}, \mathrm{C}_{\mathrm{b}}$, and $\mathrm{SO}_{4}^{2-}$, and $\mathrm{pH}$ were negatively related to total $\mathrm{Al}$ (Table 3, Fig. 6). Ammonium was highly positively related to total $\mathrm{Al}$ at $\mathrm{S} 2$, weakly positively related at S11, negatively related at S14 and S15, and not related elsewhere (Table 3). Nitrate was positively related to total $\mathrm{Al}$ in most of the mid to upper locations, such as $\mathrm{S} 10, \mathrm{~S} 13, \mathrm{~S} 14$, and $\mathrm{S} 15$, but not related elsewhere (Table 3, Fig. 6). Dissolved OC was positively related to total $\mathrm{Al}$, with some of the highest $r^{2}$ values (Table 3 ).

Magnesium, $\mathrm{Ca}^{2+}, \mathrm{C}_{\mathrm{b}}$, and $\mathrm{SO}_{4}^{2-}$ exhibited no relationship with DOC at S2, S11, and S15, and were negatively 
Table 3. Significant $(p \leq 0.05) r^{2}$ values for regression analyses of individual solute concentrations with Si (groundwater indicator), total Al (mineral soil indicator), DOC (forest floor indicator), and $\mathrm{NO}_{3}^{-}$at each sampling location at the Archer Creek watershed (Adirondack Mountains, New York, USA). + / - sign indicates the direction of the relationship. Blank cells indicate non-significant $r^{2}$ values. i.d.=insufficient data to evaluate.

\begin{tabular}{|c|c|c|c|c|c|c|c|c|c|c|c|c|}
\hline & $\mathrm{pH}$ & $\mathrm{NH}_{4}^{+}$ & $\mathrm{Mg}$ & $\mathrm{Ca}$ & $\mathrm{C}_{\mathrm{b}}^{1}$ & $\mathrm{SO}_{4}^{2-}$ & $\mathrm{Si}$ & $\mathrm{NO}_{3}^{-}$ & DON & Total N & DOC & Total Al \\
\hline \multicolumn{13}{|c|}{$-\mathrm{Si}-$} \\
\hline 2 & +0.14 & & +0.22 & +0.26 & +0.24 & +0.20 & 1 & -0.11 & & -0.12 & & -0.24 \\
\hline 9 & i.d. & i.d. & i.d. & i.d. & i.d. & i.d. & 1 & i.d. & i.d. & i.d. & i.d. & i.d. \\
\hline 10 & +0.46 & & +0.86 & +0.86 & +0.88 & +0.96 & 1 & & & & -0.90 & -0.85 \\
\hline 11 & +0.43 & & +0.71 & +0.48 & +0.63 & +0.66 & 1 & & & & -0.11 & \\
\hline 12 & i.d. & i.d. & i.d. & i.d. & i.d. & i.d. & 1 & i.d. & i.d. & i.d. & i.d. & i.d. \\
\hline 13 & i.d. & i.d. & i.d. & i.d. & i.d. & i.d. & 1 & i.d. & i.d. & i.d. & i.d. & i.d. \\
\hline 14 & -0.25 & +0.21 & & +0.59 & +0.56 & +0.83 & 1 & -0.38 & -0.14 & -0.34 & -0.39 & -0.13 \\
\hline 15 & +0.30 & +0.27 & +0.83 & +0.87 & +0.86 & +0.76 & 1 & -0.66 & -0.17 & -0.52 & & -0.58 \\
\hline \multicolumn{13}{|c|}{ - total Al - } \\
\hline 2 & -0.32 & +0.70 & -0.25 & -0.16 & -0.26 & & -0.24 & & +0.29 & & +0.42 & 1 \\
\hline 9 & & & & & & & i.d. & & +0.41 & +0.24 & +0.30 & 1 \\
\hline 10 & -0.55 & & -0.68 & -0.69 & -0.70 & -0.61 & -0.85 & +0.31 & & +0.28 & +0.84 & 1 \\
\hline 11 & -0.22 & +0.20 & -0.08 & & & -0.21 & & & +0.09 & & +0.62 & 1 \\
\hline 12 & -0.92 & & -0.37 & & & -0.74 & i.d. & & & & +0.60 & 1 \\
\hline 13 & -0.80 & & -0.56 & & -0.58 & -0.83 & i.d. & +0.37 & & +0.35 & +0.67 & 1 \\
\hline 14 & +0.08 & -0.12 & & -0.12 & -0.12 & & -0.13 & +0.18 & & +0.15 & +0.12 & 1 \\
\hline 15 & -0.26 & -0.15 & -0.55 & -0.56 & -0.57 & -0.40 & -0.58 & +0.29 & +0.29 & +0.36 & +0.43 & 1 \\
\hline \multicolumn{13}{|c|}{$-\mathrm{DOC}-$} \\
\hline 2 & -0.05 & +0.07 & & & & +0.08 & & -0.13 & +0.15 & & 1 & +0.42 \\
\hline 9 & -0.38 & & -0.59 & -0.36 & -0.45 & -0.49 & i.d. & & & & 1 & +0.30 \\
\hline 10 & -0.42 & & -0.69 & -0.70 & -0.71 & -0.57 & -0.90 & & & & 1 & +0.84 \\
\hline 11 & -0.08 & +0.24 & & & & -0.19 & -0.11 & -0.16 & +0.12 & & 1 & +0.62 \\
\hline 12 & -0.49 & & & & -0.42 & & i.d. & & & & 1 & +0.60 \\
\hline 13 & -0.43 & & -0.44 & -0.46 & -0.55 & -0.55 & i.d. & & & & 1 & +0.67 \\
\hline 14 & & -0.10 & -0.07 & -0.41 & -0.40 & -0.20 & -0.39 & +0.12 & & +0.14 & 1 & +0.12 \\
\hline 15 & & & & & & & & & +0.17 & & 1 & +0.43 \\
\hline \multicolumn{13}{|c|}{$-\mathrm{NO}_{3}^{-}-$} \\
\hline 2 & -0.18 & & -0.15 & -0.15 & -0.14 & -0.09 & -0.11 & 1 & & +0.89 & -0.13 & \\
\hline 9 & -0.64 & & -0.35 & & -0.25 & & i.d. & 1 & & +0.86 & & \\
\hline 10 & -0.22 & & -0.49 & -0.50 & -0.49 & -0.25 & & 1 & & +0.91 & & +0.31 \\
\hline 11 & & -0.12 & & & & & & 1 & & +0.52 & -0.16 & \\
\hline 12 & & & & & & -0.43 & i.d. & 1 & & +0.97 & & \\
\hline 13 & & & & & & -0.40 & i.d. & 1 & & +0.97 & & +0.37 \\
\hline 14 & +0.05 & & & -0.34 & -0.33 & -0.22 & -0.38 & 1 & & +0.76 & +0.12 & +0.18 \\
\hline 15 & -0.16 & & & & & & -0.66 & 1 & & +0.77 & & +0.29 \\
\hline
\end{tabular}

${ }^{1} \mathrm{C}_{\mathrm{b}}$ is the sum of basic cations: $\mathrm{K}^{+}, \mathrm{Na}^{+}, \mathrm{Mg}^{2+}$, and $\mathrm{Ca}^{2+}$.

related to DOC elsewhere, with $r^{2}$ ranging from 0.1 to 0.7 (Table 3, Fig. 7). Concentrations of DOC spanned a much wider range at $\mathrm{S} 2$ and $\mathrm{S} 11$ than elsewhere in the watershed. Increases in $\mathrm{NO}_{3}^{-}$were independent of DOC, except at S2, $\mathrm{S} 11$, and S14 where the two were weakly negatively related (Fig. 7). Dissolved ON was weakly positively related to DOC at S14 only. pH decreased with increases in DOC concentration (Table 3).
Magnesium, $\mathrm{Ca}^{2+}, \mathrm{C}_{\mathrm{b}}, \mathrm{pH}, \mathrm{SO}_{4}^{2-}$, and $\mathrm{Si}$ concentration decreased in response to increases in $\mathrm{NO}_{3}^{-}$in many locations, or were not related (Table 3, Fig. 8). Ammonium was weakly related at S11 only, DON was not related, while total $\mathrm{N}$ was highly positively related to $\mathrm{NO}_{3}^{-}$concentrations at each sampling location (Table 3). 

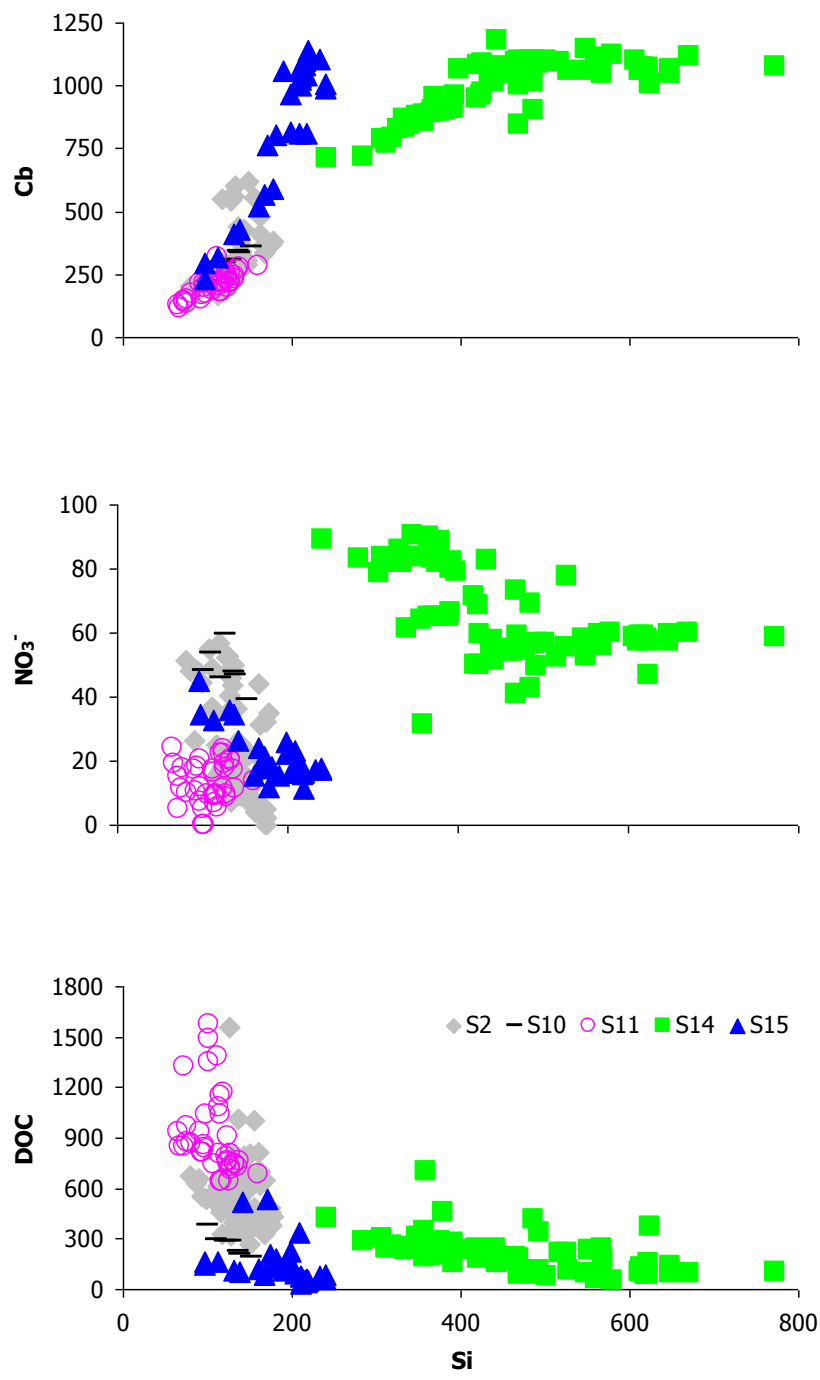

Fig. 5. Spatial relationships between concentrations $\left(\mu \mathrm{mol} \mathrm{L}^{-1}\right)$ of sum of base cations $\left(\mathrm{C}_{\mathrm{b}}\right), \mathrm{NO}_{3}^{-}, \mathrm{DOC}$, and $\mathrm{Si}$ at several ${ }^{2}$ sampling locations in the Archer Creek watershed. ${ }^{2}$ Other locations had insufficient data to evaluate. $\mathrm{C}_{\mathrm{b}}$ includes $\mathrm{K}^{+}, \mathrm{Na}^{+}, \mathrm{Mg}^{2+}, \mathrm{Ca}^{2+}$.

3.4 Temporal dynamics in solute concentration and isotopic composition

The main effect of period was significant for $\delta^{15} \mathrm{~N}-\mathrm{NO}_{3}^{-}$ only. All other solutes had significant interactions described below. Average $\delta^{15} \mathrm{~N}-\mathrm{NO}_{3}^{-}$values ranged from a low of $+1.4 \%$ o during snowmelt to $+4.1 \%$ o during fall. Period interacted with year for $\mathrm{pH}$, and for the concentrations of $\mathrm{NH}_{4}^{+}$, $\mathrm{NO}_{3}^{-}$, total N, DOC, and total Al (Table 2).

Snowmelt in 2001 exhibited the lowest $\mathrm{pH}$ among the studied period*year interactions. Summer during both years exhibited the highest $\mathrm{pH}$, but it was not significantly different than $\mathrm{pH}$ in winter, spring, or fall (Fig. 9). Nitrate concentrations peaked during snowmelt of 2001 at $\sim 69 \mu \mathrm{mol} \mathrm{L}^{-1}$. Snowmelt 2002, and both winters exhibited next highest
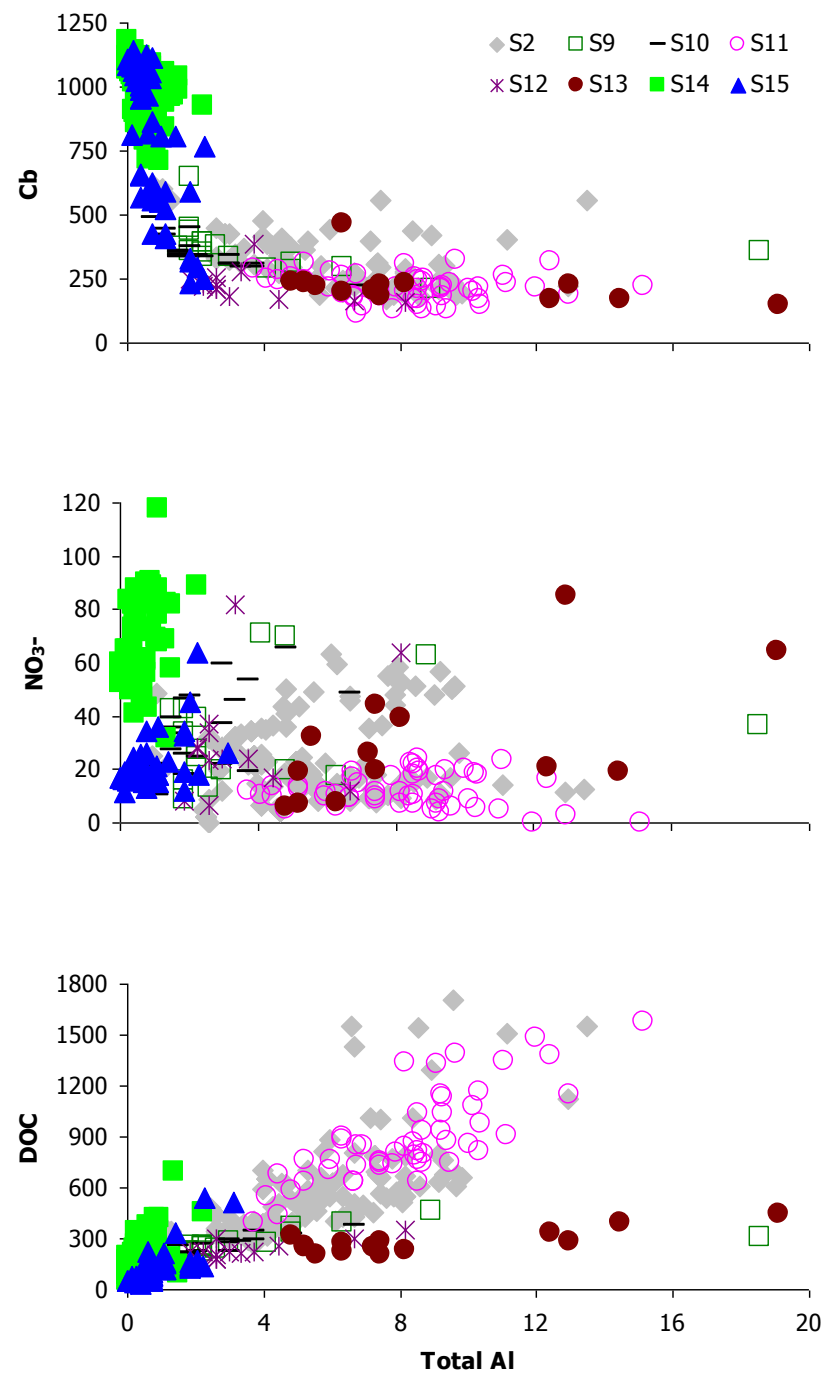

Fig. 6. Spatial relationships between concentrations $\left(\mu \mathrm{mol} \mathrm{L}^{-1}\right)$ of sum of base cations $\left(\mathrm{C}_{\mathrm{b}}\right), \mathrm{NO}_{3}^{-}, \mathrm{DOC}$, and total $\mathrm{Al}$ at sampling locations in the Archer Creek watershed. $\mathrm{C}_{\mathrm{b}}$ includes $\mathrm{K}^{+}, \mathrm{Na}^{+}$, $\mathrm{Mg}^{2+}, \mathrm{Ca}^{2+}$.

$\mathrm{NO}_{3}^{-}$concentrations. Spring and fall had similar $\mathrm{NO}_{3}^{-}$concentrations in both years and periods (Fig. 9). Total $\mathrm{N}$ followed the $\mathrm{NO}_{3}^{-}$pattern closely. Dissolved OC peaked in spring and fall of 2001, and dipped in summer 2002, otherwise it stayed fairly consistent (Fig. 9). There was more total $\mathrm{Al}$ in spring, summer, and fall of 2001 than during those periods in 2002, with winter and snowmelt exhibiting similar values for both years (Fig. 9).

\subsection{Relationships among solutes across periods}

Magnesium, $\mathrm{Ca}^{2+}$, and $\mathrm{C}_{\mathrm{b}}$ increased with $\mathrm{Si}$; the highest regression coefficients ( $r^{2}$ values) were observed during snowmelt and spring (Table 4, Fig. 10). Ammonium was not related to $\mathrm{Si}$, but $\mathrm{NO}^{3-}$ was positively related, with highest 

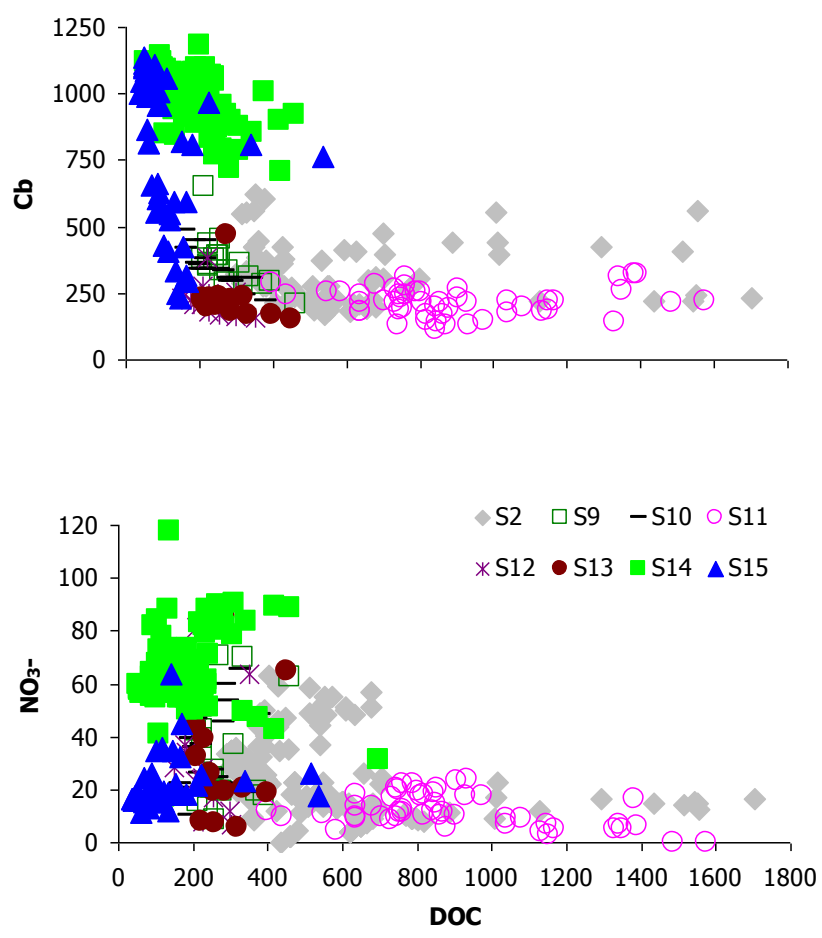

Fig. 7. Spatial relationships between concentrations $\left(\mu \mathrm{mol} \mathrm{L}^{-1}\right)$ of sum of base cations $\left(\mathrm{C}_{\mathrm{b}}\right), \mathrm{NO}_{3}^{-}$, and DOC at sampling locations in the Archer Creek watershed. $\mathrm{C}_{\mathrm{b}}$ includes $\mathrm{K}^{+}, \mathrm{Na}^{+}, \mathrm{Mg}^{2+}, \mathrm{Ca}^{2+}$.

$r^{2}$ values during spring, summer, and fall (Table 4, Fig. 10). Sulfate was positively related to $\mathrm{Si}$ in all but fall period, with the highest $r^{2}$ in snowmelt (Table 4). pH was positively related to $\mathrm{Si}$ in all periods but summer. Dissolved OC and total $\mathrm{Al}$ were negatively related to $\mathrm{Si}$ with highest $r^{2}$ in spring (Table 4, Fig. 10). Dissolved ON was not related to Si except in spring, when the relationship was weak and negative (Table 4).

Total Al concentrations were negatively related to most solutes, except $\mathrm{NH}_{4}^{+}$, DON, and DOC, which increased with increasing Al during most periods (Table 4, Fig. 11). Spring exhibited highest $r^{2}$ values for most solutes with $\mathrm{Al}$, followed by fall (Table 4).

Concentration of DOC was not as strongly related to solute concentrations as $\mathrm{Si}$ or total $\mathrm{Al}$ (Table 4, Fig. 12). Except for $\mathrm{NH}_{4}^{+}$, DON, and total $\mathrm{Al}$, all other solutes were negatively related to DOC (Table 4).

Calcium, $\mathrm{C}_{\mathrm{b}}, \mathrm{SO}_{4}^{2-}$, and $\mathrm{Si}$ concentrations, and $\mathrm{pH}$ increased with increases in $\mathrm{NO}_{3}^{-}$in all discharge periods; $r^{2}$ ranged from 0.14 for $\mathrm{SO}_{4}^{2-}$ in summer and fall, to 0.90 for $\mathrm{Si}$ in spring (Table 4, Fig. 13). Magnesium also increased with $\mathrm{NO}_{3}^{-}$from winter through spring, but these two solutes were not related in summer or fall. Total $\mathrm{N}$ increased in snowmelt through fall, but was not related in winter. Weakly negatively related to $\mathrm{NO}_{3}^{-}$were $\mathrm{NH}_{4}^{+}$and DON during snowmelt
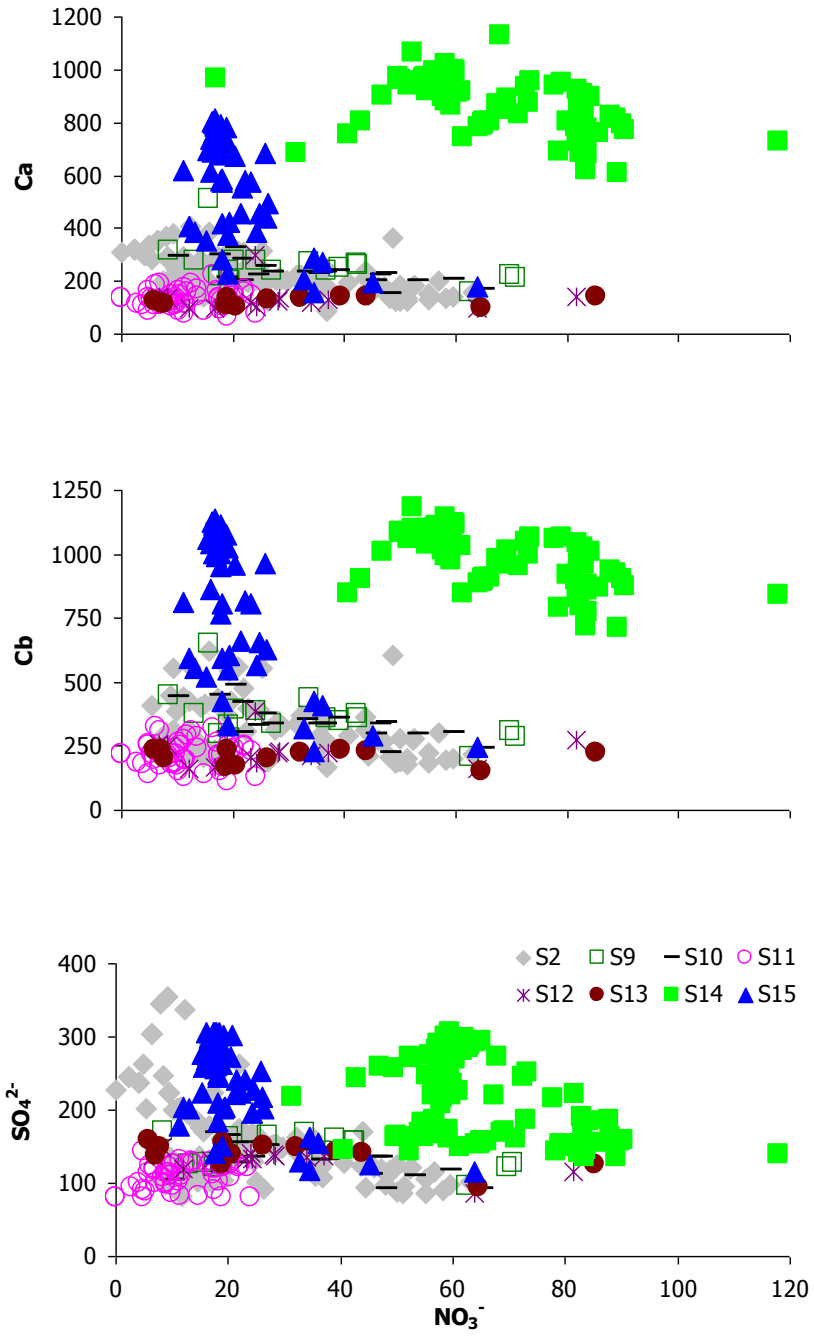

Fig. 8. Spatial relationships between concentrations $\left(\mu \mathrm{mol} \mathrm{L}{ }^{-1}\right)$ of $\mathrm{Ca}^{2+}$, sum of base cations $\left(\mathrm{C}_{\mathrm{b}}\right), \mathrm{SO}_{4}^{2-}$, and $\mathrm{NO}_{3}^{-}$at sampling locations in the Archer Creek watershed. $\mathrm{C}_{\mathrm{b}}$ includes $\mathrm{K}^{+}, \mathrm{Na}^{+}$, $\mathrm{Mg}^{2+}, \mathrm{Ca}^{2+}$.

and spring only, and DON additionally in fall. Dissolved OC and total $\mathrm{Al}$ were negatively related to $\mathrm{NO}_{3}^{-}$all year around (Table 4).

\subsection{Relationships of solutes to discharge}

Most solutes exhibited significant regressions with daily discharge at $\mathrm{S} 2, \mathrm{~S} 10, \mathrm{~S} 11, \mathrm{~S} 14$, and $\mathrm{S} 15 ; \mathrm{NO}_{3}^{-}$and daily discharge had significant $r^{2}$ in every sampling location (Table 5). Most solutes had significant regressions with adjusted cumulative discharge per period at S2, S10, S14, and S15, and $\mathrm{NO}_{3}^{-}$was significant in every sampling location. Most solutes had significant regressions with previous period's cumulative discharge at $\mathrm{S} 2, \mathrm{~S} 10, \mathrm{~S} 11$, and $\mathrm{S} 14 ; \mathrm{NO}_{3}^{-}$was highly positively related to previous cumulative discharge at S9, not related at S14 or S15, and could not be evaluated at S12 or S13 (Table 5). 

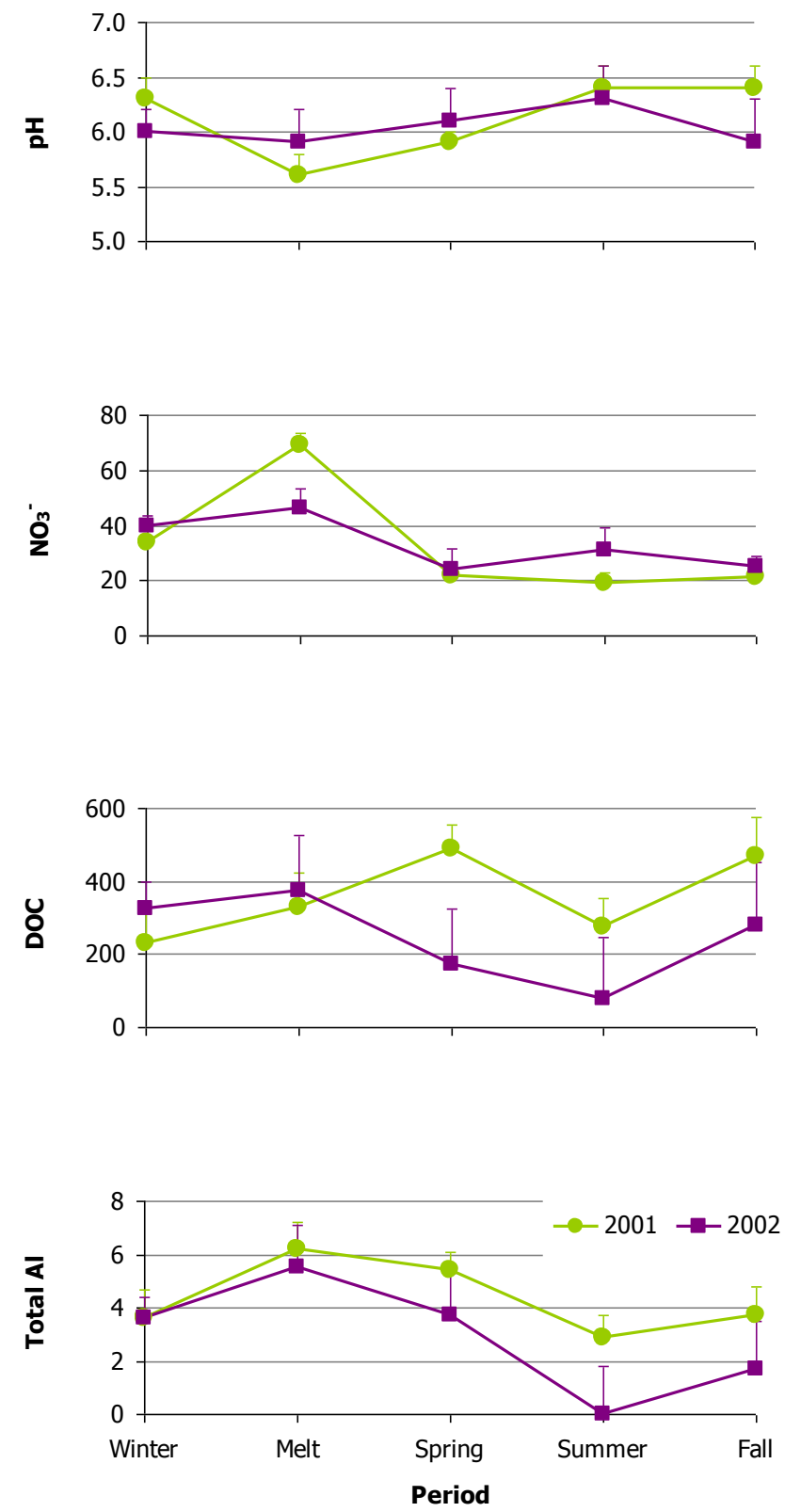

Fig. 9. Average $\mathrm{pH}$, and concentrations $\left(\mu \mathrm{mol} \mathrm{L}^{-1}\right)$ of $\mathrm{NO}_{3}^{-}$, $\mathrm{DOC}$, and total $\mathrm{Al}$ in two years at five discharge periods, with standard errors (+) shown.

\section{Discussion}

4.1 Spatial patterns in solute concentrations are driven by solute sources and may be moderated by discharge levels

Archer Creek watershed has a complex topography which includes two wetlands and two groundwater sources. The forested wetland at S11 and deep groundwater at S14 exerted dominant influence over stream water chemistry at their respective locations. That dominance was attenuated else-
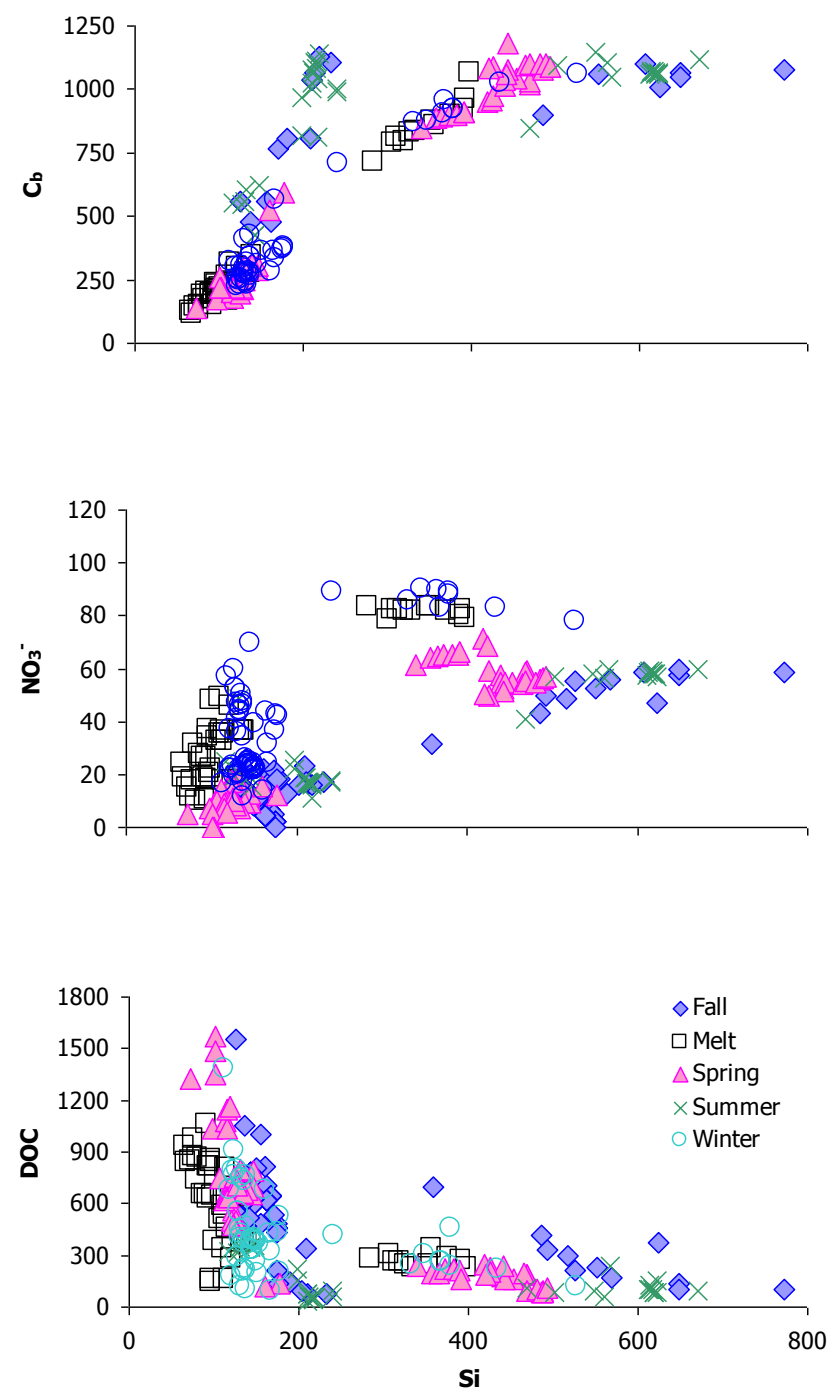

Fig. 10. Temporal relationships between concentrations $\left(\mu \mathrm{mol} \mathrm{L}^{-1}\right)$ of sum of base cations $\left(\mathrm{C}_{\mathrm{b}}\right), \mathrm{NO}_{3}^{-}, \mathrm{DOC}$, and $\mathrm{Si}$ across discharge periods. $\mathrm{C}_{\mathrm{b}}$ includes $\mathrm{K}^{+}, \mathrm{Na}^{+}, \mathrm{Mg}^{2+}, \mathrm{Ca}^{2+}$.

where. The importance of a smaller, alder-supporting wetland at S2 (watershed outlet), and shallow groundwater at S15 was moderated by discharge levels. We also identified discharge-dependent source areas for individual solutes, including total $\mathrm{Al}$ at $\mathrm{S} 13$ and $\mathrm{NO}_{3}^{-}$at $\mathrm{S} 14$ during snowmelt. We discuss these and other observations in detail below.

The wetland draining to S11 exerted its dominance over stream water chemistry through highest DOC, and some of the lowest $\mathrm{NO}_{3}^{-}$concentrations observed in Archer Creek. Further, S11 exhibited discharge-dependent peaks in total $\mathrm{Al}$ and troughs in $\mathrm{pH}$ (Table 2; Fig. 4). High DOC and low $\mathrm{NO}_{3}^{-}$are consistent with incomplete and slow organic matter breakdown in conditions of low oxygen in wetlands. Low $\mathrm{NO}_{3}^{-}$concentrations may be additionally due to denitrification. A trend toward depleted values of $\delta^{15} \mathrm{~N}-\mathrm{NO}_{3}^{-}$, 
Table 4. Significant $(p \leq 0.05) r^{2}$ values for regression analyses of individual solute concentrations with five discharge periods at the Archer Creek watershed (Adirondack Mountains, New York, USA). +/- sign indicates the direction of the relationship. Blank cells indicate nonsignificant $r^{2}$ values. i.d.=insufficient data to evaluate.

\begin{tabular}{|c|c|c|c|c|c|c|c|c|c|c|c|c|}
\hline & $\mathrm{pH}$ & $\mathrm{NH}_{4}$ & $\mathrm{Mg}$ & $\mathrm{Ca}$ & $\mathrm{C}_{\mathrm{b}}^{1}$ & $\mathrm{SO}_{4}^{2-}$ & $\mathrm{Si}$ & $\mathrm{NO}_{3}^{-}$ & DON & Total N & DOC & Total Al \\
\hline & \multicolumn{12}{|c|}{$-\mathrm{Si}-$} \\
\hline Winter & +0.63 & & +0.54 & +0.94 & +0.93 & +0.52 & 1 & +0.59 & & +0.49 & -0.14 & -0.30 \\
\hline Snowmelt & +0.72 & & +0.90 & +0.98 & +0.98 & +0.80 & 1 & +0.76 & & +0.74 & -0.41 & -0.68 \\
\hline Spring & +0.66 & & +0.79 & +0.98 & +0.98 & +0.68 & 1 & +0.90 & -0.22 & +0.90 & -0.65 & -0.81 \\
\hline Summer & & & -0.37 & +0.67 & +0.33 & +0.12 & 1 & +0.85 & & +0.71 & -0.14 & -0.21 \\
\hline \multirow[t]{2}{*}{ Fall } & +0.21 & & -0.21 & +0.72 & +0.47 & & 1 & +0.93 & & +0.79 & -0.27 & -0.41 \\
\hline & \multicolumn{12}{|c|}{ - total Al - } \\
\hline Winter & -0.54 & +0.19 & -0.43 & -0.29 & -0.33 & -0.35 & -0.30 & -0.13 & +0.21 & & +0.48 & 1 \\
\hline Snowmelt & -0.66 & & -0.67 & -0.57 & -0.59 & -0.56 & -0.68 & -0.28 & +0.15 & -0.23 & +0.46 & 1 \\
\hline Spring & -0.66 & +0.19 & -0.76 & -0.66 & -0.68 & -0.72 & -0.81 & -0.62 & +0.13 & -0.49 & +0.65 & 1 \\
\hline Summer & -0.29 & -0.12 & -0.24 & -0.53 & -0.60 & -0.31 & -0.21 & -0.20 & & -0.13 & +0.74 & 1 \\
\hline \multirow[t]{2}{*}{ Fall } & -0.63 & +0.15 & & -0.38 & -0.38 & & -0.41 & -0.31 & +0.66 & & +0.89 & 1 \\
\hline & \multicolumn{12}{|c|}{$-\mathrm{DOC}-$} \\
\hline Winter & -0.40 & & -0.31 & -0.17 & -0.19 & -0.38 & -0.14 & -0.13 & +0.15 & -0.05 & 1 & +0.48 \\
\hline Snowmelt & -0.67 & +0.12 & -0.51 & -0.32 & -0.34 & -0.44 & -0.41 & -0.62 & +0.30 & -0.49 & 1 & +0.46 \\
\hline Spring & -0.45 & +0.40 & -0.50 & -0.40 & -0.42 & -0.65 & -0.65 & -0.43 & +0.22 & -0.26 & 1 & +0.65 \\
\hline Summer & -0.18 & & -0.18 & -0.39 & -0.43 & & -0.14 & -0.10 & +0.11 & & 1 & +0.74 \\
\hline \multirow[t]{2}{*}{ Fall } & -0.45 & +0.20 & & -0.21 & -0.22 & & -0.27 & -0.22 & +0.74 & & 1 & +0.89 \\
\hline & \multicolumn{12}{|c|}{$-\mathrm{NO}_{3}^{-}-$} \\
\hline Winter & +0.37 & & +0.06 & +0.56 & +0.51 & +0.07 & +0.59 & 1 & & & -0.11 & -0.13 \\
\hline Snowmelt & +0.62 & -0.15 & +0.58 & +0.51 & +0.52 & +0.38 & +0.76 & 1 & -0.12 & +0.95 & -0.62 & -0.28 \\
\hline Spring & +0.58 & -0.10 & +0.55 & +0.86 & +0.84 & +0.50 & +0.90 & 1 & -0.12 & +0.90 & -0.43 & -0.62 \\
\hline Summer & +0.11 & & & +0.55 & +0.36 & +0.14 & +0.85 & 1 & & +0.83 & -0.09 & -0.20 \\
\hline Fall & +0.24 & & & +0.55 & +0.36 & +0.14 & +0.93 & 1 & -0.12 & +0.87 & -0.22 & -0.31 \\
\hline
\end{tabular}

${ }^{1} \mathrm{C}_{\mathrm{b}}$ is the sum of basic cations: $\mathrm{K}^{+}, \mathrm{Na}^{+}, \mathrm{Mg}^{2+}$, and $\mathrm{Ca}^{2+}$.

observed at both wetland-influenced sampling locations, has been associated with low rates of organic matter turnover in water-logged conditions (Kendall, 1998).

Our observations support earlier work in this watershed by Inamdar et al. (2004), who noted that wetlands controlled DOC concentrations during a summer storm at the watershed outlet. Our data indicate that wetlands control DOC concentrations in the lower reaches of this watershed throughout the year, with S11 contributing more than S2. The positive relationships between DOC and total Al in all discharge periods, and strong relationship between DOC and $\mathrm{Al}$ at S10, S12, and S13 (Fig. 6; Tables 3 and 4) indicate that soil horizons in some of the mid elevations also contribute DOC. Forest floors constitute the largest sources of DOC across temperate forests (Michalzik et al., 2001), but it is not clear how that changes when wetlands are present. In our watershed, the relative contribution of wetlands to DOC appears to be far more important than that of the forest floor (Fig. 2 this study; Park et al., 2003; Inamdar et al., 2004; Piatek et al., 2005).
Groundwater at S14 clearly exerted a major influence over stream chemistry at upper elevations, providing high $\mathrm{pH}$ through high concentrations of $\mathrm{Mg}^{2+}, \mathrm{Ca}^{2+}$ and $\mathrm{Si}$, and low Al. Water at S14 originates from deep groundwater sources (McHale et al., 2002). Calcium, $\mathrm{SO}_{4}^{2-}$ and $\mathrm{Si}$ were negatively related to daily, cumulative, and previous cumulative discharge (Table 5) suggesting dilution of groundwater by atmospheric solutions mostly during high discharge.

Groundwater at S14 was also an apparent source of $\mathrm{NO}_{3}^{-}$. However, the negative relationship across sampling points between $\mathrm{NO}_{3}^{-}$and $\mathrm{Si}$ - the groundwater indicator - and a positive one between $\mathrm{NO}_{3}^{-}$and $\mathrm{Al}$ - the mineral soil indicator - suggest that the source of $\mathrm{NO}_{3}^{-}$is soil rather than groundwater. Soil source of $\mathrm{NO}_{3}^{-}$is further supported by positive relationships of $\mathrm{NO}_{3}^{-}$with daily and cumulative discharge levels indicating that when more of the soil profile is flushed, stream responds with higher $\mathrm{NO}_{3}^{-}$levels. Formation of $\mathrm{NO}_{3}^{-}$in $\mathrm{S} 14$ was attributed in earlier studies in this 

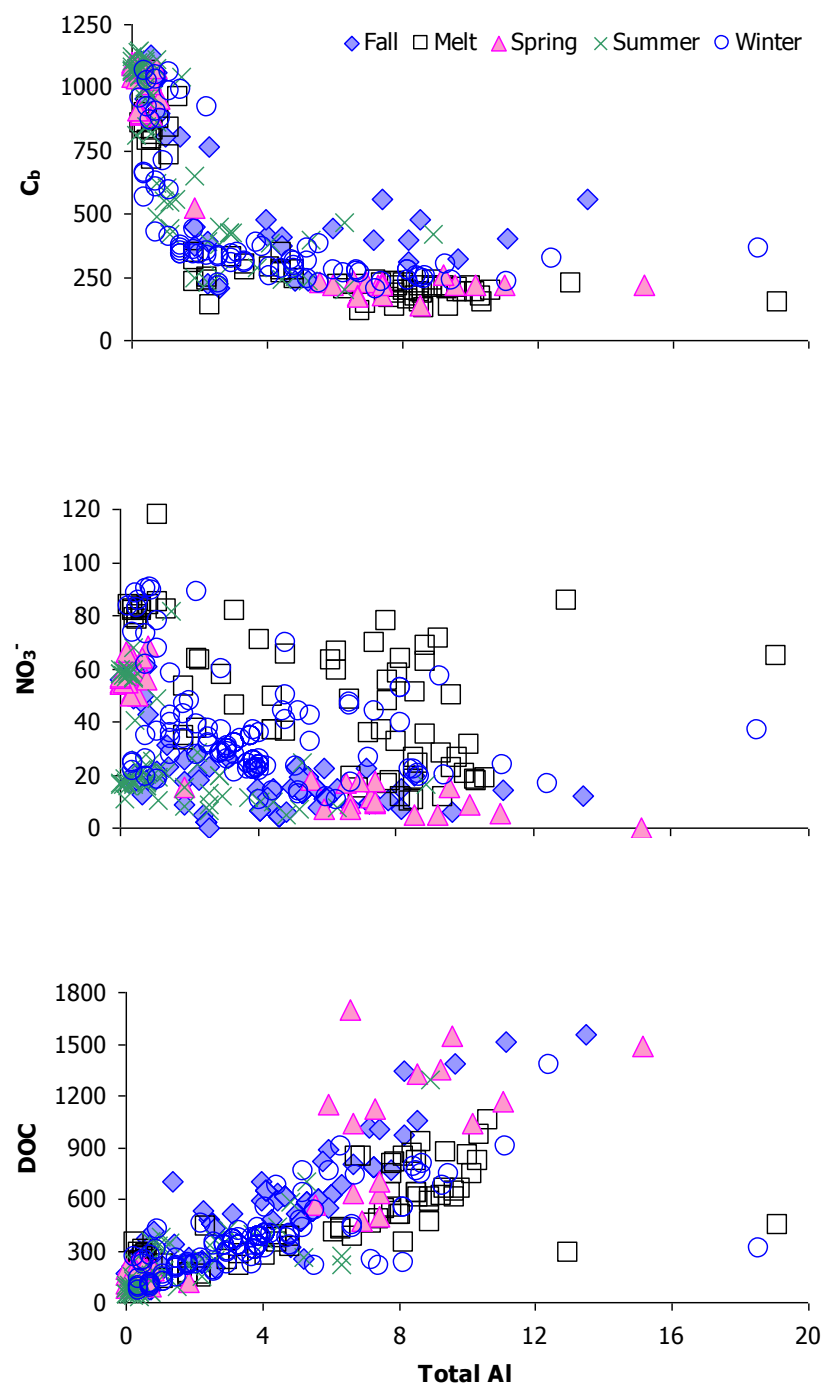

Fig. 11. Temporal relationships between concentrations $(\mu \mathrm{mol} \mathrm{L}-1)$ of sum of base cations $\left(\mathrm{C}_{\mathrm{b}}\right), \mathrm{NO}_{3}^{-}, \mathrm{DOC}$, and total $\mathrm{Al}$ across discharge periods. $\mathrm{C}_{\mathrm{b}}$ includes $\mathrm{K}^{+}, \mathrm{Na}^{+}, \mathrm{Mg}^{2+}$, $\mathrm{Ca}^{2+}$.

watershed to vegetation composition, and linked to Ca levels in soils (Christopher et al., 2006; Page et al., 2008). Sugar maple (Acer saccharum), in high proportion in the S14 subwatershed, is known for its association with high soil $\mathrm{NO}_{3}^{-}$ (Lovett et al., 2002; Lovett and Mitchell 2004; Christopher et al., 2006) probably due to fast decomposition of sugar maple foliar litter. Upper soil horizons were hotspots for nitrification in the Catskill Mountains of New York, which have similar topography to the Adirondack Mountains (Welsch et al., 2001).

Therefore, two sources of $\mathrm{NO}_{3}^{-}$are evident in the Archer Creek watershed. One source is discharge-independent and originates in groundwater (at S14), while the other is discharge-dependent and is flushed directly from the soil profile in upper watershed. The actual functioning of this most
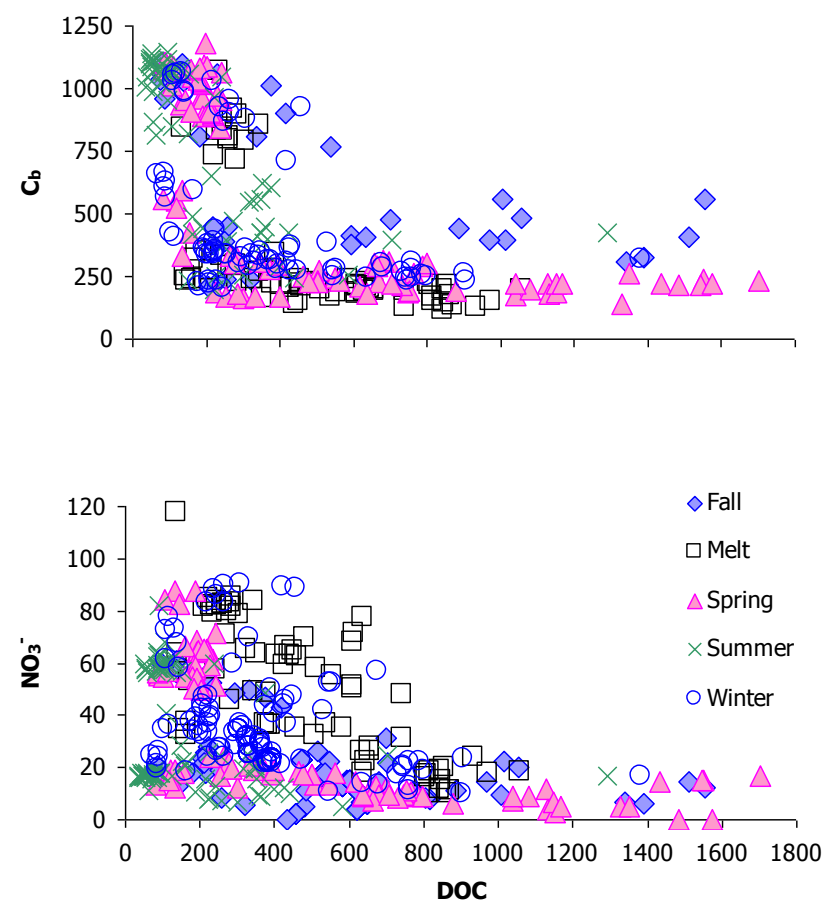

Fig. 12. Temporal relationships between concentrations $(\mu \mathrm{mol} \mathrm{L}-1)$ of sum of base cations $\left(\mathrm{C}_{\mathrm{b}}\right), \mathrm{NO}_{3}^{-}$, and DOC across discharge periods. $\mathrm{C}_{\mathrm{b}}$ includes $\mathrm{K}^{+}, \mathrm{Na}^{+}, \mathrm{Mg}^{2+}, \mathrm{Ca}^{2+}$.

likely includes the flushing-draining mechanism described by Creed et al. (1996), in which once produced in soils, $\mathrm{NO}_{3}^{-}$ movement may be to stream or to groundwater, depending on hydrologic connectivity at the sampling location. Thus, groundwater is probably recharged with $\mathrm{NO}_{3}^{-}$during periods when connectivity between soil and stream may be lost due to insufficient saturation in that location, which can still support draining. Groundwater serves as the secondary source of $\mathrm{NO}_{3}^{-}$when soil nitrate sources are likely to be disconnected from stream due to low soil saturation during the growing season.

Two sources of $\mathrm{NO}_{3}^{-}$are consistent with several earlier observations in this watershed. First, a combined isotopic and chemistry analysis showed that the main source of $\mathrm{NO}_{3}^{-}$ during snowmelt was soil (Piatek et al., 2005). Second, the source of $\mathrm{NO}_{3}^{-}$during summer storms determined by hydrograph separations appeared to be groundwater (McHale et al., 2002). Further, isotopic values of $\delta^{18} \mathrm{O}-\mathrm{NO}_{3}^{-}$in stream water in this study were well below those for atmospheric $\mathrm{NO}_{3}^{-}$of $+72.0 \%$ at this site (Piatek et al., 2005), showing that nitrification, not atmospheric deposition, was the source of $\mathrm{NO}_{3}^{-}$in stream water; both ground and soil water have similar isotopic values of $\mathrm{NO}_{3}^{-}$(Kendall, 1998; Piatek et al., 2005). This study extends the evidence for lack of presence of atmospherically-derived $\mathrm{NO}_{3}^{-}$in creek water from snowmelt and fall storms to other parts of the year in our watershed and elsewhere (Burns and Kendall, 2002; Pardo et 
al., 2004; Piatek et al., 2005; Mitchell et al., 2006; Hales et al., 2007) and indicates high level of atmospheric $\mathrm{NO}_{3}^{-}$retention by forests with long-term atmospheric $\mathrm{N}$ deposition and symptoms of N saturation (Aber et al., 1989, 1998; Stoddard, 1994).

$\mathrm{S} 15$, located in close proximity to $\mathrm{S} 14$, exhibited contrasting stream chemistry to S14. Nitrate concentrations were on average $60 \%$ lower at $\mathrm{S} 15$ than at $\mathrm{S} 14$, and $\mathrm{Mg}^{2+}$ was almost twice as much at S15 in summer and fall than at S14. Chemistry at S15 varied with discharge levels clearly indicating a potential influence of soil water when discharge levels were high. This supports earlier studies on the sources of water in these two sampling locations; S15, discharging shallow groundwater, most likely has a more immediate connectivity with soil water than S14, the source of deep groundwater (McHale et al., 2002).

In the current analysis, $\mathrm{SO}_{4}^{2-}$ concentration, highest at $\mathrm{S} 14$ and $\mathrm{S} 15$, was highly positively related to $\mathrm{Si}$, and negatively related to $\mathrm{Al}$ or $\mathrm{DOC}$, suggesting that groundwater in upper elevation is an important contributor of this solute. An internal source of $\mathrm{SO}_{4}^{2-}$ in this watershed was also clearly shown using isotopic analyses (Campbell et al., 2006). Temporal patterns of $\mathrm{SO}_{4}^{2-}$ versus $\mathrm{Si}$ also indicate that groundwater was the source of this solute (Table 4). The high concentrations of $\mathrm{SO}_{4}^{2-}$ in fall and low during snowmelt (Table 5) reflect the addition of wetland-derived $\mathrm{SO}_{4}^{2-}$ in fall 2002 to $\mathrm{SO}_{4}^{2-}$ normally present in this watershed from groundwater (Mitchell et al., 2006), and dilution of groundwater and groundwater-related solutes during snowmelt.

Wetland source of $\mathrm{SO}_{4}^{2-}$, observed during fall storms following an unusually dry summer (Mitchell et al., 2006) now appears to be episodic. In fact, both wetland-draining sampling locations, S2 and S11, had significantly lower average $\mathrm{SO}_{4}^{2-}$ concentrations than the groundwater sources. Models of climate change predict an increase in extremes in weather patterns such as droughts (Meehl et al., 2000; Kharin and Zwiers, 2005), therefore, wetland-derived $\mathrm{SO}_{4}^{2-}$ may be found more commonly under changing climatic conditions. Drought-induced oxidation of previously-reduced and wetland-stored sulfur was also described in catchments in Eastern Canada (Schiff et al., 2005).

$\mathrm{S} 13$ contributed the majority of $\mathrm{Al}$ to the Archer Creek system, with smaller amounts added by wetlands. Contributions were highly dependent on discharge, except at S11, where specific conditions may change the way discharge affects $\mathrm{Al}$ and how the two are related. At S13, the extensive subwatershed area of 41.9 ha (31\% of total watershed) would be expected to contribute a large proportion of soil-derived solutes under conditions of hydrologic connectivity with the stream. A substantial decrease in Al between S13 and S9 may be indicative of dilution or a presence of an Al sink. S9, as a mixing area for $\mathrm{S} 13, \mathrm{~S} 14$, and $\mathrm{S} 15$ (Fig. 1), receives high levels of $\mathrm{Si}, \mathrm{Ca}^{2+}, \mathrm{Mg}^{2+}$, and $\mathrm{SO}_{4}^{2-}$, making $\mathrm{Al}$ complexation and precipitation possible.
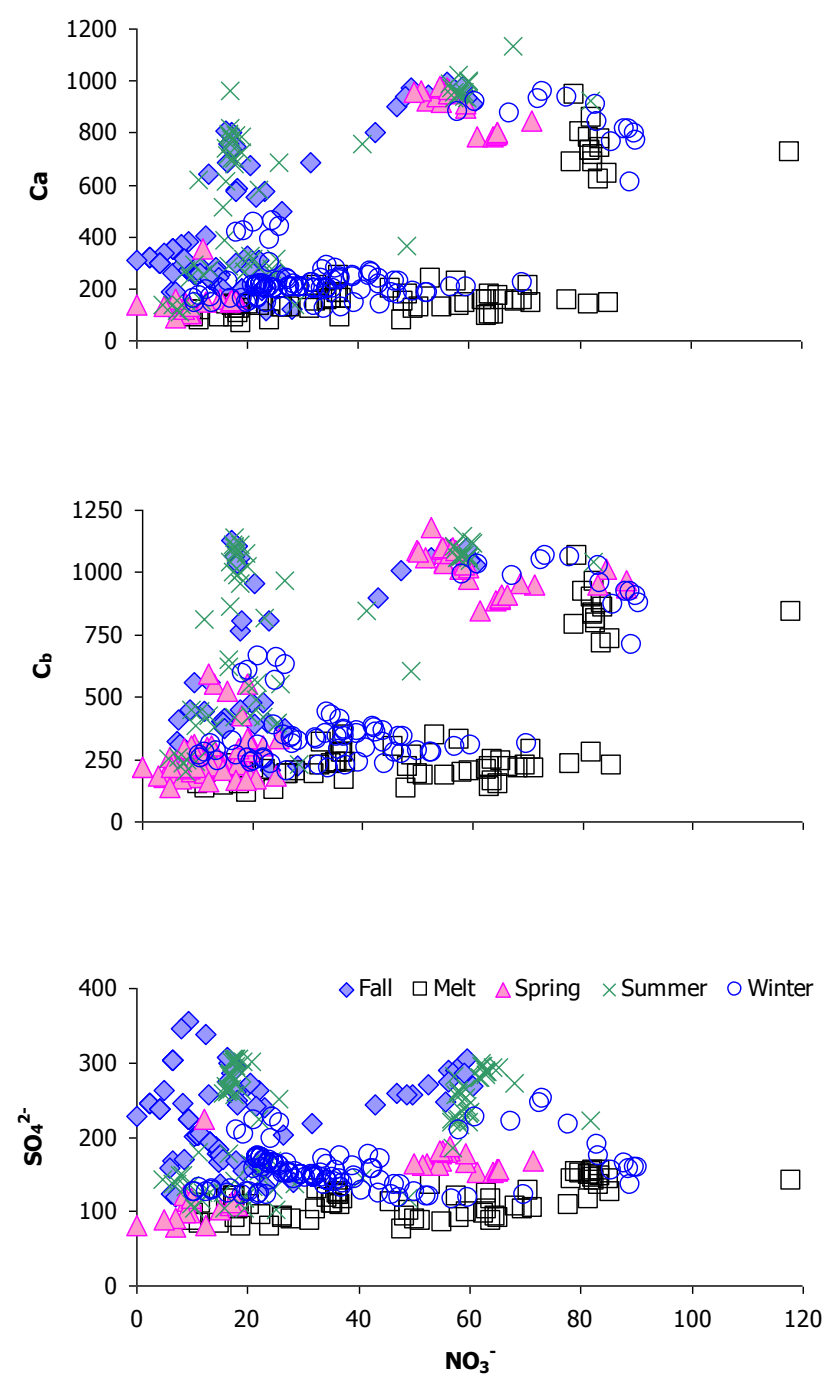

Fig. 13. Temporal relationships between concentrations $\left(\mu \mathrm{mol} \mathrm{L}^{-1}\right)$ of $\mathrm{Ca}^{2+}$, sum of base cations $\left(\mathrm{C}_{\mathrm{b}}\right), \mathrm{SO}_{4}^{2-}$, and $\mathrm{NO}_{3}^{-}$across discharge periods. $\mathrm{C}_{\mathrm{b}}$ includes $\mathrm{K}^{+}, \mathrm{Na}^{+}, \mathrm{Mg}^{2+}$, $\mathrm{Ca}^{2+}$.

4.2 Does chemistry at the outlet adequately represent chemistry in the watershed?

Previous studies in this and in many other watersheds focused on chemistry at the watershed outlet only. As the mixing area, it is assumed that the outlet reflects the variety of sources and processes within the watershed. Our study sheds some light on the validity of this assumption. In this study, we have detected much spatial variation in surface water chemistry. The main effect of sampling location was significant for $\mathrm{DOC}, \mathrm{SO}_{4}^{2-}, \mathrm{NO}_{3}^{-}$, and total $\mathrm{N}$, while for many other solutes, the effect of sampling location was dependent on discharge period.

Pair-wise comparisons (each sampling location with every other one) indicated that most consistent differences in DOC, 
Table 5. Significant $(p \leq 0.05) r^{2}$ values for regression analyses of daily, cumulative, and previous cumulative discharge on solute concentrations at sampling locations 2-15 in the Archer Creek watershed (Adirondack Mountains, New York, USA). $+/-$ sign indicates the direction of the relationship. Blank cells indicate non-significant $r^{2}$ values. i.d.=insufficient data to evaluate.

\begin{tabular}{|c|c|c|c|c|c|c|c|c|c|c|c|}
\hline & $\mathrm{pH}$ & $\mathrm{Mg}$ & $\mathrm{Ca}$ & $\mathrm{C}_{\mathrm{b}}^{1}$ & $\mathrm{SO}_{4}^{2-}$ & $\mathrm{Si}$ & $\mathrm{NO}_{3}^{-}$ & DON & Total N & DOC & Total Al \\
\hline & \multicolumn{11}{|c|}{ - daily discharge $\left(\mathrm{mm}^{2}\right.$ day $\left.^{-1}\right)-$} \\
\hline 2 & -0.13 & -0.31 & -0.32 & -0.32 & -0.10 & -0.57 & +0.29 & & & & +0.32 \\
\hline 9 & i.d. & i.d. & i.d. & i.d. & i.d. & i.d. & i.d. & i.d. & i.d. & i.d. & i.d. \\
\hline 10 & & -0.88 & -0.88 & -0.88 & -0.87 & -0.89 & +0.46 & & & +0.88 & +0.84 \\
\hline 11 & -0.17 & -0.28 & -0.16 & -0.24 & -0.15 & -0.47 & +0.30 & & +0.19 & & \\
\hline 12 & i.d. & i.d. & i.d. & i.d. & i.d. & i.d. & +0.36 & i.d. & i.d. & i.d. & i.d. \\
\hline 13 & & -0.33 & & & & & +0.36 & & & & \\
\hline 14 & & -0.07 & -0.60 & -0.58 & -0.23 & -0.41 & +0.28 & +0.16 & +0.36 & +0.26 & +0.07 \\
\hline \multirow[t]{2}{*}{15} & -0.27 & -0.58 & -0.59 & -0.59 & -0.60 & -0.70 & +0.65 & & +0.39 & & +0.49 \\
\hline & \multicolumn{11}{|c|}{ - cumulative discharge $\left(\mathrm{mm} \mathrm{period}^{-1}\right)-$} \\
\hline 2 & -0.17 & -0.68 & -0.56 & -0.66 & & & +0.54 & & +0.15 & & +0.27 \\
\hline 9 & i.d. & i.d. & i.d. & i.d. & i.d. & i.d. & +0.66 & i.d. & i.d. & i.d. & i.d. \\
\hline 10 & & -0.68 & -0.67 & -0.68 & -0.73 & -0.72 & +0.73 & & & +0.66 & +0.65 \\
\hline 11 & & & & & & & +0.39 & & +0.41 & -0.15 & \\
\hline 12 & i.d. & i.d. & i.d. & i.d. & i.d. & i.d. & +0.59 & i.d. & i.d. & i.d. & i.d. \\
\hline 13 & i.d. & i.d. & i.d. & i.d. & i.d. & i.d. & +0.80 & i.d. & i.d. & i.d. & i.d. \\
\hline 14 & +0.19 & +0.06 & -0.36 & -0.34 & -0.57 & -0.69 & +0.39 & +0.10 & +0.39 & +0.37 & +0.16 \\
\hline 15 & -0.26 & -0.81 & -0.87 & -0.86 & -0.69 & -0.82 & +0.49 & +0.21 & +0.44 & & +0.52 \\
\hline \multicolumn{12}{|c|}{ - previous cumulative discharge $\left(\mathrm{mm}\right.$ period $\left.^{-1}\right)-$} \\
\hline 2 & +0.10 & -0.28 & -0.31 & -0.27 & -0.49 & -0.15 & +0.10 & -0.21 & -0.26 & & \\
\hline 9 & i.d. & i.d. & i.d. & i.d. & i.d. & i.d. & +0.80 & i.d. & i.d. & i.d. & i.d. \\
\hline 10 & & -0.68 & -0.67 & -0.68 & -0.73 & -0.72 & & & & +0.66 & +0.65 \\
\hline 11 & -0.34 & -0.33 & -0.40 & -0.38 & -0.46 & -0.30 & -0.10 & & -0.10 & & \\
\hline 12 & i.d. & i.d. & i.d. & i.d. & i.d. & i.d. & i.d. & i.d. & i.d. & i.d. & i.d. \\
\hline 13 & i.d. & i.d. & i.d. & i.d. & i.d. & i.d. & i.d. & i.d. & i.d. & i.d. & i.d. \\
\hline 14 & +0.9 & +0.25 & & & -0.37 & -0.18 & & & & & -0.7 \\
\hline 15 & & & & & & & & -0.24 & & -0.15 & \\
\hline
\end{tabular}

${ }^{1} \mathrm{C}_{\mathrm{b}}$ is the sum of basic cations: $\mathrm{K}^{+}, \mathrm{Na}^{+}, \mathrm{Mg}^{2+}$, and $\mathrm{Ca}^{2+}$.

$\mathrm{SO}_{4}^{2-}, \mathrm{NO}_{3}^{-}$, and total $\mathrm{N}$ were between watershed outlet and $\mathrm{S} 14$, the deep groundwater source, S15, the shallow groundwater source, and S11, the extensive wetland, and related to specific solute levels. However, discharge-related changes in concentrations at the source areas were well reproduced at the watershed outlet. Chemistry at the outlet was comparable to stream chemistry elsewhere in the watershed outside of the source areas, both in terms of specific concentrations and discharge-related dynamics. Interestingly, linkage of $\mathrm{NO}_{3}^{-}$ with DOC that has been suggested in earlier studies (Park et al., 2003; Piatek et al., 2005), has not been confirmed here, as evidenced by weak or no relationships between $\mathrm{NO}_{3}^{-}$and DOC across both space and time (Tables 3 and 4). Lack of consistent relationships between $\mathrm{NO}_{3}^{-}$and DOC across studies in this watershed is not surprising given that previous studies focused on watershed outlet, which has significantly lower levels of solutes than their source areas, and individual source areas may be differently affected by discharge levels.

\subsection{Temporal patterns in solute concentrations are driven by discharge dynamics}

The main effect of period was limited to $\delta^{15} \mathrm{~N}-\mathrm{NO}_{3}^{-}$, probably reflecting insufficient data in some of the observed periods. Otherwise, period interacted with sampling point for $\mathrm{Mg}^{2+}, \mathrm{Ca}^{2+}, \mathrm{C}_{\mathrm{b}}, \mathrm{Si}, \mathrm{pH}$, and $\mathrm{Al}$, and with year for $\mathrm{NO}_{3}^{-}$, total N, DOC, and Al (Table 2).

Snowmelt diluted solutes originating in groundwater at S14 and S15 and flushed to stream those solutes which originated in soil horizons. This effect of snowmelt was strongest at the respective solute sources. Snowmelt, spanning at most 30 days around mid-April, carries the largest percentage of the annual discharge in the shortest amount of time (Table 1). 
This effect of high discharge is related to the steep topography of this watershed and illustrates that large volumes of water have the capacity to explore and flush a large percentage of the upland contributing areas which results in flushing of higher amounts of soil-derived solutes.

By contrast, periods with low discharge such as summer and fall were generally characterized by higher $\mathrm{pH}, \mathrm{Mg}^{2+}$, $\mathrm{Ca}^{2+}, \mathrm{C}_{\mathrm{b}}$, and among the lowest $\mathrm{Al}$ and DOC concentrations (Figs. 3 and 4). Low-discharge periods reflect maximum contributions from groundwater in our creek system (McHale et al., 2002) and decreasing contributions of soil water as watershed saturation decreases and hydrologic connectivity is gradually lost. In extreme cases, water ceases to flow between sampling locations, as we observed at S12 during the drought of summer 2002. As mainly groundwater, characteristics of summer discharge may reflect the dominant type of parent materials in the watershed, one high in $\mathrm{Ca}$ (subwatershed S14), and one high in $\mathrm{Mg}$ (subwatershed S15). Despite a dry spell in one of the two observed summers (2002), and a series of storms in one of the two observed autumns (2002), these two periods did not result in stream water chemistry that stood out as statistically different (at $p \leq 0.05$ ) from others. Most likely, this reflects variability in solute concentrations in this topographically-diverse catchment.

\subsection{Are high or unusual discharge periods representative of average solute levels?}

Unusual weather patterns may be representative of more extreme weather predicted for climate change scenarios (Meehl et al., 2000; Kharin and Zwiers, 2005). We had a unique opportunity to evaluate whether differences in biogeochemical patterns among periods with unusually low and unusually high discharges are still representative of patterns observed during average discharge. Specifically, we compared solute concentrations for snowmelt 2001, summer 2002, and fall 2002 with all other discharge periods. Snowmelt 2001 had the highest discharge of any period in the two years of study. Summer 2002 brought an unusually long drought, while fall 2002 featured several storms which followed the prolonged summer drought.

In general, snowmelt 2001 stood out as the most biogeochemically different among all other periods, with among the lowest $\mathrm{pH}$ and $\mathrm{Mg}^{2+}$, highest $\mathrm{NO}_{3}^{-}$and total $\mathrm{N}$, and among the highest total Al (Fig. 9). Discharge in snowmelt 2001 constituted $46 \%$ of total that year, and it was $61 \mathrm{~mm}$ more than in 2002 (Table 1). Highest $\mathrm{NO}_{3}^{-}$and lowest $\mathrm{pH}$ during snowmelt 2001, and among the lowest total $\mathrm{Al}$ and DOC during drought in summer 2002 suggest that, with an increase in extreme weather patterns, we could expect issues with stream acidity and the presence of high levels of $\mathrm{NO}_{3}^{-}$during highdischarge snowmelts, and low DOC and AL inputs, during droughts.

Fall 2002, despite several storms and an additional source of $\mathrm{SO}_{4}^{2-}$ from wetland oxidation (Mitchell et al., 2006), was surprisingly similar to other periods. Therefore, whether high-discharge events adequately represent stream chemistry at average discharge levels depends on solute and discharge level. It appears that an understanding of watershed-specific temporal context of solute expression will be important in this regard.

\section{Conclusions}

We have refined our understanding of solute generation in the Archer Creek watershed to include a multi-dimensional mosaic of space and discharge periods. In this mosaic, base cations are derived from groundwater discharging in upper watershed, and DOC primarily from wetlands. In the absence of unusual climatic events such as droughts, $\mathrm{SO}_{4}^{2-}$ is also contributed by groundwater. Nitrate produced in soils is flushed to stream when catchment saturation allows hydrologic connectivity between source-areas and stream, otherwise $\mathrm{NO}_{3}^{-}$apparently drains to groundwater at $\mathrm{S} 14$ which discharges it to stream when nitrification is likely to be limited or when soil source-areas are hydrologically disconnected from stream. Individual source-areas (S13) contribute most of the $\mathrm{Al}$ at high discharge. Watershed outlet does not appear to reproduce high concentrations typical of sourceareas in the watershed. Similarly, observations at highdischarge events alone do not characterize solute dynamics at all other discharge levels. However, watershed outlet represents relative solute dynamics quite well, and high discharge events are responsible for the largest solute fluxes. Therefore, whether the spatial or temporal resolution obtained at watershed outlet or at high discharge events respectively is sufficient or not must be dictated by research objectives.

Acknowledgements. We thank P. Hazlett and an anonymous reviewer for helpful comments on an earlier version of this manuscript.

Edited by: N. Verhoest

\section{References}

Aber, J. D., Nadelhoffer, K. J. Steudler, P., and Mellilo, M. J.: Nitrogen saturation in northern hardwood forest ecosystems, Bioscience, 39, 378-386, 1989.

Aber, J. D., McDowell, W., Nadelhoffer, K., Magill, A., Berntson, G., Kamakea, M., McNulty, S., Currie, W., Rustad, L., and Fernandez, I.: Nitrogen saturation in temperate forest ecosystems: hypotheses revisited, Bioscience, 48, 921-934, 1998.

Aber, J. D., Ollinger, S. V., Driscoll, C. T., Likens, G. E., Holmes, R. T., Freuder, R. J., and Goodale, C. L.: Inorganic nitrogen losses from a forested ecosystem in response to physical, chemical, biotic and climatic perturbations, Ecosystems, 5, 648-658, 2002.

Baron, J. S. and Campbell, D. H.: Nitrogen fluxes in high elevation Colorado Rocky Mountain Basin, Hydrol. Process., 11, 783-799, 1997. 
Bischoff, J. M., Bukaveckas, P., Mitchell, M. J., and Hurd, T.: Nitrogen storage and cycling of a forested wetland: implications for watershed N processing, Water Air Soil Poll., 128, 97-114, 2001.

Boyer, E. W., Hornberger, G. M., Bencala, K. E., and McKnight, D. M.: Response characteristics of DOC flushing in an alpine Catchment, Hydrol. Process., 11, 1635-1647, 1997.

Brooks, P. D. and Williams, M. W.: Snowpack controls on nitrogen cycling and export seasonally snow-covered catchments, Hydrol. Process., 13, 2177-2190, 1999.

Buffam, I., Galloway, J. N., Blum, L. K., and McGlathery, K. J.: A stormflow/baseflow comparison of dissolved organic matter concentrations and bioavailability in an Appalachian stream, Biogeochemistry, 53, 269-306, 2001.

Burns, D. A. and Kendall, C.: Analysis of $\delta^{15} \mathrm{~N}$ and $\delta^{18} \mathrm{O}$ to differentiate $\mathrm{NO}_{3}^{-}$sources in runoff at two watersheds in the Catskill Mountains of New York, Water Resour. Res., 38(5), 1051, doi:10.1029/2001WR000292, 2002.

Campbell, D. H., Kendall, C., Chang, C. C. Y., Silva, S. R., and Tonnessen, K. A.: Pathways for nitrate release from an alpine watershed: determination using $\delta^{15} \mathrm{~N}$ and $\delta^{18} \mathrm{O}$, Water Resour. Res., 38(5), 1052, doi:10.1029/2001WR000294, 2002.

Campbell, J., Mitchell, M. J., and Mayer, B.: Isotopic analysis of $\mathrm{NO}_{3}^{-}$and $\mathrm{SO}_{4}^{2-}$ mobility during winter in two adjacent watersheds in the Adirondack Mountains, New York, J. Geophys. Res., 111, G04007, doi:10.1029/2006JG000208, 2006.

Casciotti, K., Sigman, L., Galanter, D. M., Hastings, M., Bohlke, J. K., and Hilkert, A.: Measurement of the oxygen isotopic composition of nitrate in marine and fresh waters using the denitrifier method, Anal. Chem., 74, 4905-4912, 2002.

Christopher, S. F., Page, B. D., Campbell, J. L., and Mitchell, M. J.: Contrasting stream water $\mathrm{NO}_{3}^{-}$and $\mathrm{Ca}^{2+}$ in two nearly adjacent catchments: the role of soil $\mathrm{Ca}$ and forest vegetation, Global Change Biol., 12, 364-381, 2006.

Christopher, S. F., Mitchell, M. J., McHale, M. R., Boyer, E. W., Burns, D. A., and Kendall, C.: Factors controlling nitrogen release from two forested catchments with contrasting hydrochemical responses, Hydrol. Process., 22, 46-62, 2008.

Creed, I. F., Band, L. E., Foster, N. W., Morrison, I. K., Nicolson, J. S., Semkins, R. S., and Jeffries, D. S.: Regulation of Nitrate-N release from temperate forests: a test of the $\mathrm{N}$ flushing hypothesis, Water Resour. Res., 32, 3337-3354, 1996.

Creed, I. F. and Band, L. E.: Export of nitrogen from catchments within a temperate forest: evidence for a unifying mechanism regulated by variable source area dynamics, Water Resour. Res., 34, 3105-3120, 1998.

Dent, C. L. and Grimm, N. B.: Spatial heterogeneity of stream water nutrient concentrations over successional time, Ecology, 80, 2283-2298, 1999.

Eimers, M. C., Watmough, S. A., and Buttle, J. M.: Long-term trends in dissolved organic carbon concentration: a cautionary note, Biogeochemistry, 87, 71-81, 2008.

Hales, H. C., Ross, D. S., and Lini, A.: Isotopic signature of nitrate in two contrasting watersheds of Brush Brook, Vermont, USA, Biogeochemistry, 84, 51-66, 2007.

Harriman, R., Gillespie, E., King, D., Watt, A. W., Christie, A. E. G., Cowan, A. A., and Edwards, T.: Short-term ionic responses as indicators of hydrochemical processes in the Allt A'Mharcaidh catchment, western Cairngorms, Scotland, J. Hydrol., 116, 267-
285, 1990.

Harrison, A. F., Taylor, K., Scott, A., Poskitt, J., Benham, D., Grace, J., Chaplow, J., and Rowland, P.: Potential effects of climate change on DOC release from three different soil types on the Northern Pennines UK: examination using field manipulation experiments, Global Change Biol., 14, 687-702, 2008.

Hill, A. R.: Nitrogen dynamics of storm runoff in the riparian zone of a forested watershed, Biogeochemistry, 20, 19-44, 1993.

Hurd, T. M., Raynal, D. J., and Schwintzer, C. R.: Symbiotic N2 fixation of Alnus incana sprugosa in shrub wetlands of the Adirondack Mountains, New York, USA, Oecologia, 126, 94103, 2001

Inamdar, S. P., Christopher, S. F., and Mitchell, M. J.: Export mechanisms for dissolved organic carbon and nitrate during summer storm events in a glaciated forested catchment in New York, USA, Hydrol. Process., 18, 2651-2661, 2004.

Ito, M., Mitchell, M. J., Driscoll, C. T., and Roy, K. M.: Nitrogen input-output budgets for lake-watersheds in the Adirondack region of New York, Biogeochemistry, 72, 283-314, 2005.

Ito, M., Mitchell, M. J., Driscoll, C. T., Newton, R. M., Johnson, C. E., and Roy, K. M.: Controls on surface water chemistry in two lake-watersheds in the Adirondack region of New York: differences in nitrogen solute sources and sinks, Hydrol. Process., 21, 1249-1264, 2007.

Kendall, C.: Tracing nitrogen sources and cycling in catchments, in: Isotope Tracers in catchment hydrology, Elsevier Science, BV, 519-576, 1998.

Kharin, V. V. and Zwiers, F. W.: Estimating extremes in transient climate change simulations, J. Climate, 18, 1156-1173, 2005.

Legendre, P. and Fortin, M. J.: Spatial pattern and ecological analysis, Vegetatio, 80, 107-138, 1989.

Lovett, G. M., Weathers, K. C., and Arthur, M. A.: Control of nitrogen loss from forested watersheds by soil carbon:nitrogen ratio and tree species composition, Ecosystems, 5, 712-728, 2002.

Lovett, G. M. and Mitchell, M. J.: Sugar maple and nitrogen cycle in the forests of eastern North America, Front. Ecol. Environ., 2, 81-88, 2004.

McHale, M. R.: Hydrologic controls of nitrogen cycling in an Adirondack Watershed, Ph.D. Dissertation, State University of New York, College of Environmental Science and Forestry, Syracuse, New York, 230 pp., 1999.

McHale, M. R., McDonnell, J. J., Mitchell, M. J., and Cirmo, C. P.: A field based study of soil-and groundwater nitrate release in an Adirondack forested watershed, Water Resour. Res., 38, 10291038, 2002.

Meehl, G. A., Zwiers, F., Evans, J., Knutson, T., Mearns, L., and Whetton, P.: Trends in extreme weather and climate events: issues related to modeling extremes in projections of future climate change, B. Am. Meteorol. Soc., 81, 427-436, 2000.

Michalzik, B., Kalbitz, K., Park, J.-H., Sollinger, S., and Matzner, E.: Fluxes and concentrations of dissolved organic carbon and nitrogen - a synthesis for temperate forests, Biogeochemistry, 52, 173-205, 2001.

Mitchell, M. J., Raynal, D. J., and Driscoll, C. T.: Biogeochemistry of a forested watershed in the central Adirondack Mountains: temporal changes and mass balances, Water Air Soil Poll., 88, 355-369, 1996.

Mitchell, M. J., McHale, P. J., Inamdar, S. P., and Raynal, D. J.: Role of within-lake processes and hydrobiogeochemical changes 
over 16 years in a watershed in the Adirondack Mountains of New York State, USA, Hydrol. Process., 15, 1951-1965, 2001.

Mitchell, M. J., Driscoll, C. T., Inamdar, S., McGee, G., Mbila, M., and Raynal, D. J.: Nitrogen biogeochemistry in the Adirondack Mountains of New York: hardwood ecosystems and associated surface waters, Environ. Pollut., 123, 355-364, 2003.

Mitchell, M. J., Piatek, K. B., Christopher, S., Mayer, B., Kendall, C., and McHale, P.: Solute sources in stream water during consecutive fall storms in a northern hardwood forest watershed: a combined hydrological, chemical, and isotopic approach, Biogeochemistry, 78, 217-246, 2006.

Ohrui, K., Mitchell, M. J., and Bischoff, J. M.: Effect of landscape position on $\mathrm{N}$ mineralization and nitrification in a forested watershed in the Adirondack Mountains of New York, Can. J. Forest Res., 29, 497-508, 1999.

Ogawa, A., Shibata, H., Suzuki, K., Mitchell, M. J., and Ikegami, Y.: Relationship of topography to surface water chemistry with particular focus on nitrogen and organic carbon solutes within a forested watershed in Hokkaido, Japan, Hydrol. Process., 20, 251-265, 2006.

Page, B. D., Bullen, T. D., and Mitchell, M. J.: Influences of calcium availability and tree species on the cycling of $\mathrm{Ca}$ isotopes in soil, vegetation, and stream water, Biogeochemistry, 88, 1-13, 2008.

Pardo, L. H., Kendall, C., Pett-Ridge, J., and Chang, C. C. Y.: Evaluating the source of streamwater nitrate using $\delta^{15} \mathrm{~N}$ and $\delta^{18} \mathrm{O}$ in nitrate in two watersheds in New Hampshire, USA, Hydrol. Process., 18, 2699-2712, 2004.

Park, J. H., Mitchell, M. J., McHale, P. J., Christopher, S. F., and Myers, T. P.: Interactive effects of changing climate and atmospheric deposition on $\mathrm{N}$ and $\mathrm{S}$ biogeochemistry in a forested watershed of the Adirondack Mountains, New York State, Global Change Biol., 9, 1602-1619, 2003.
Perakis, S. S. and Hedin, L. O.: Fluxes and fates of nitrogen in soil of an unpolluted old-growth temperate forest, southern Chile, Ecology, 82, 2245-2260, 2001.

Piatek, K. B., Mitchell, M. J., Silva, S. R., and Kendall, C.: Sources of nitrate in snowmelt discharge: evidence from water chemistry and stable isotopes of nitrate, Water Air Soil Poll., 165, 13-35, 2005.

Schiff, S. L., Spoelstra, J., Semkin, R. G., and Jeffries, D. S.: Drought-induced pulses of $\mathrm{SO}_{4}^{2-}$ from a Canadian shield wetland: use of $\delta^{34} \mathrm{~S}$ and $\delta^{18} \mathrm{O}$ in $\mathrm{SO}_{4}^{2-}$ to determine sources of sulfur, Appl. Geochem., 20, 691-700, 2005.

Shepard, J. P., Mitchell, M. J., Scott, T. J., Zhang, Y. M., and Raynal, D. J.: Measurements of wet and dry deposition in a northern hardwood forest, Water Air Soil Poll., 48, 225-238, 1989.

Sigman, D. M., Casciotti, K. L., Andreani, M., Barford, C., Galanter, M., and Bohlke, J. K.: A bacterial method for the nitrogen isotopic analysis of nitrate in marine and fresh waters, Anal. Chem., 73, 4145-4153, 2001.

Somers, R. C.: Soil classification, genesis, morphology, and variability with the Central Adirondack Region of New York, Ph.D. Dissertation, State University of New York, College of Environmental Science and Forestry, Syracuse, NY, 746 pp., 1986.

Stoddard, J. L.: Long-term changes in watershed retention of nitrogen: its causes in aquatic consequences, in Environmental chemistry of lakes and reservoirs advances in chemistry, American Chemical Society, Washington, DC, USA, 223-284, 1994.

Wagener, S. M., Oswood, S. W., and Schimmel, J. P.: Rivers and Soils: parallels in carbon and nutrient processing, Bioscience, 48, 104-108, 1998.

Welsch, D. L., Kroll, C. N., McDonnell, J. J., and Burns, D. A.: Topographic controls on the chemistry of subsurface stormflow, Hydrol. Process., 15, 1925-1938, 2001. 